\title{
Transmetalation of Acyclic Tungsten Carbenes to Coinage Metals: Dis- tinct Behavior of Silver Towards Carbene Transfer and Hydrolysis
}

\author{
Alberto Toledo, Vanesa Salamanca, Teresa Pérez-Moro and Ana C. Albéniz* \\ IU CINQUIMA/Química Inorgánica. Universidad de Valladolid. 47071 Valladolid (Spain).
}

\begin{abstract}
The transmetalation of acyclic monoamino and alkoxo carbenes from tungste
three metals by analyzing the new metal carbenes formed and also their decomposition products in solution. The ease of transmetalation follows the trend: $\mathrm{Au}>\mathrm{Cu}>\mathrm{Ag}$ and the gold carbenes can be isolated, a copper carbene could be detected but we found no experimental evidence of the formation of any silver carbene. The electrophilic character of copper and gold carbenes is supported by the identity of the products formed upon hydrolysis of the carbenes involved. Silver shows a distinct behavior and the presence of $\mathrm{Ag}^{+}$ions in an acetonitrile solution of a tungsten aminocarbene leads to the formal protonation of the carbene fragment to give an iminium salt. This outcome, a seemingly nucleophillic behavior, is unexpected for group 11 carbenes but DFT calculations show that the protonation of a putative cationic silver carbene is energetically accessible.
\end{abstract}

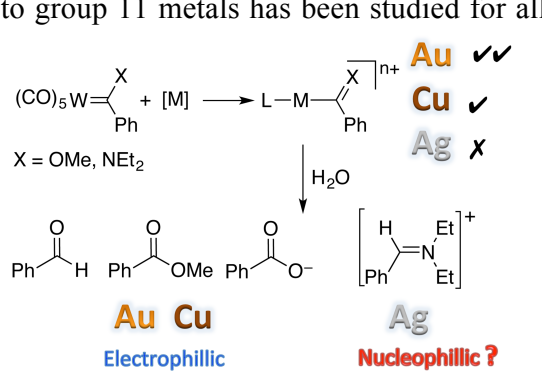

\section{INTRODUCTION}

The carbene chemistry of group 11 metals spans from the useful and robust spectator $\mathrm{N}$-heterocyclic carbene (NHC), ${ }^{1}$ diaminotype carbene (NAC), ${ }^{2}$ or cyclic alkylamino carbene (CAAC) ligands, ${ }^{3}$ widely used in catalysis, to the reactive carbene fragments from diazoderivatives or other precursors, used as reagents and incorporated into the products. All group 11 metals are involved in catalytic reactions that may form intermediate reactive metal carbenes in one of the steps of the process. ${ }^{4}$ For example, the mechanisms of alkene cyclopropanation, ${ }^{5}$ carbene insertion reactions into $\mathrm{C}-\mathrm{H}$ bonds of alkanes, ${ }^{6}$ coupling reactions of diazocompounds, ${ }^{7}$ or the Wolff rearrangement, ${ }^{8}$ involve the formation of elusive metal-carbene species from the diazoderivatives used as reagents and this has been supported by DFT calculations. ${ }^{9}$ Cycloheptatrienes as carbene precursors by a retro-Buchner reaction have been used in a gold-catalyzed cyclopropanation reaction with the likely participation of a gold carbene species. ${ }^{10}$ Even if no reactant carbene source is present, many gold catalyzed-transformations of unsaturated compounds are explained by the formation of reactive species that can be considered gold-carbenes with more or less metal-stabilized carbocation character. ${ }^{11}$ This subject has been discussed in the literature and efforts have been made to synthesize and study nonstabilized gold carbenes that could give information about the nature of those complexes. ${ }^{12}$ As a result, a number of weakly stabilized AuCRR' carbenes ( $R=R^{\prime}=$ hydrocarbyl, $\left.H\right)$ have been reported and their structures analyzed. ${ }^{13}$ Non-stabilized carbenes of copper are even more elusive than gold carbenes but nonetheless examples of CuCRR' derivatives have been reported. ${ }^{14}$ Only one example of a monomeric silver carbene has been disclosed. ${ }^{14 \mathrm{~g}}$ In general, those studies show that the M$\mathrm{C}$ (carbene) bond length conforms to a single bond and that the metal to carbene back-bonding is quite small or often negligible.

There is still a lot to learn about reactive group 11 metal carbenes and there are few studies that compare the behavior of the three metals towards the same carbene fragment and reaction conditions. ${ }^{9 \mathrm{a}, 1 \mathrm{gg}, 15}$ When there is enough data, structural or otherwise, to compare the three metals significant differences between them and deviations from a periodic behavior are found. The work we describe here explores the formation of group 11 metal complexes with $\mathrm{C}(\mathrm{X}) \mathrm{R}$ carbenes $\left(\mathrm{X}=\mathrm{NR}_{2}, \mathrm{OR}\right)$ by transmetalation reactions from tungsten carbenes. Since the $\mathrm{X}$ group is electron donating and capable of partially compensate the electron deficiency on the carbene carbon, an intermediate reactivity is expected for the $\mathrm{M}-\mathrm{C}(\mathrm{X}) \mathrm{R}$ fragments, when compared to NHCs or CRR' groups (Scheme 1). ${ }^{16}$ This might be useful to get information about the character and reactivity of the carbenes formed by all three metals. This strategy has been used before by us in the study of the reactivity of palladium carbenes and their migratory insertion reactions. ${ }^{17}$ Transmetalation of monoamino or monoalkoxo carbenes between group 6 and another transition metals is often the synthetic method of choice for this unstable carbene fragments that are difficult to generate by other means. ${ }^{18}$ There are some examples of this reaction involving group 11 metals that have led to the successful isolation of copper, ${ }^{19}$ and gold monoheteroatom-containing carbenes. ${ }^{20}$ With these precedents we have analyzed and compared the behavior of analogous precursor complexes of $\mathrm{Cu}, \mathrm{Ag}$ and $\mathrm{Au}$ towards tungsten $\mathrm{C}(\mathrm{X}) \mathrm{R}^{\prime}$ carbenes $\left(\mathrm{X}=\mathrm{NR}_{2}, \mathrm{OR}\right)$, both for the transmetalation and their hydrolysis reactions.

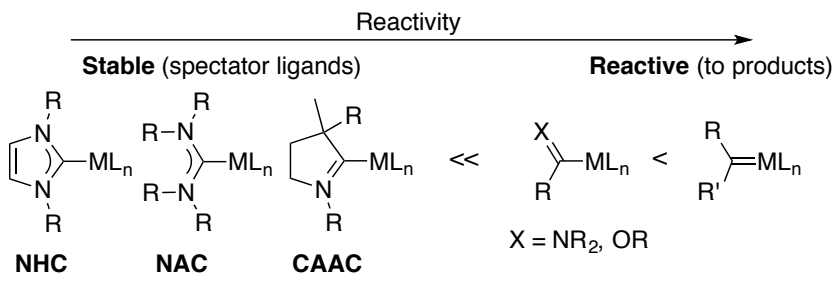

Scheme 1. Reactivity trend for metal carbenes.

\section{RESULTS AND DISCUSSION}

The direct transmetalation of the tungsten carbenes was tested using neutral and cationic group 11 precursor complexes with weakly coordinated ligands that could favor the carbene for ligand 
substitution. $[\mathrm{MCl}($ tht $)] \quad(\mathrm{M}=\mathrm{Cu}, \mathrm{Ag}, \mathrm{Au}$; tht $=$ tetrahydrothiophene) and $\left[\mathrm{Cu}(\mathrm{MeCN})_{4}\right] \mathrm{PF}_{6},\left[\mathrm{Au}(\mathrm{MeCN})_{2}\right] \mathrm{BF}_{4}$ and $\mathrm{AgBF}_{4}$ in acetonitrile were reacted with $\left[\mathrm{W}(\mathrm{CO})_{5}\{\mathrm{C}(\mathrm{X}) \mathrm{Ph}]\right\}(\mathrm{X}=$ $\left.\mathrm{NEt}_{2}, \mathbf{1 a} ; \mathrm{X}=\mathrm{OMe}, \mathbf{1 b}\right)$. The results obtained for each metal are described below.

Synthesis and reactions of gold carbene complexes. The gold(I) carbenes $\mathbf{2} \mathbf{a}$ and $\mathbf{2 b}$ were synthesized in good yields by direct and smooth transmetalation from the tungsten $(0)$ carbenes $\mathbf{1}$ to [AuCl(tht)] in either $\mathrm{CH}_{2} \mathrm{Cl}_{2}$ or acetonitrile at room temperature (Eq. 1). ${ }^{16}$ Comparing $\mathbf{2 a}$ and $\mathbf{2 b}$, the ${ }^{13} \mathrm{C}_{\text {carbene }}$ NMR resonance is $44 \mathrm{ppm}$ higher for the alkoxocarbene, in agreement with the higher electrophilic character expected for this carbene (2b) vs. the aminocarbene $\mathbf{2 a}$.

$$
\begin{aligned}
& (\mathrm{CO})_{5} \mathrm{~W}=\mathrm{Ph}_{\mathrm{Ph}}^{\mathrm{X}}+[\mathrm{AuCl}(\text { tht })] \longrightarrow \mathrm{Cl}-\mathrm{Au}-\mathrm{Ph}_{\mathrm{Ph}}^{\mathrm{X}}+\left[\mathrm{W}(\mathrm{CO})_{5} \text { (tht) }\right] \\
& \begin{array}{l}
\text { 1a, } \mathrm{X}=\mathrm{NEt}_{2} \\
\text { 1b, } \mathrm{X}=\mathrm{OMe}
\end{array} \\
& \text { 1b, } \mathrm{X}=\mathrm{OMe} \quad \text { 2a, } \mathrm{X}=\mathrm{NEt}_{2} \quad 224 \\
& \text { 2b, } X=\text { OMe } 268
\end{aligned}
$$

The X-ray crystal structures of $\mathbf{2} \mathbf{a}$ and $\mathbf{2 b}$ were determined and they show two independent molecules in the unit cell (see SI). ${ }^{21}$ Both complexes show a linear coordination for the gold center, where the $\mathrm{Au}-\mathrm{C}_{\text {carbene }}$ bond distances conform to the typical range reported before for gold carbenes, ${ }^{20 \mathrm{~b}-\mathrm{f}, 21}$ and are consistent with a single bond between a $\mathrm{sp}^{2}$ carbon atom and the metal (Figure 1). ${ }^{22}$ The $\mathrm{C}-\mathrm{X}$ bond lengths are short and show a double bond character as a result of the lone pair donation from $\mathrm{X}$ to the electrophilic carbene carbon. Therefore, the representation used for the group 11 carbenes in Eq. 1 and throughout the paper reflects these structural parameters and bonding situation. ${ }^{16}$ Aurophilic interactions with an adjacent molecule are weak for $\mathbf{2 b}(\mathrm{Au}-\mathrm{Au}$ distance 3.4481(2) $\AA$ ) and even less important for 2a (shortest Au$\mathrm{Au}$ distance $3.6762 \AA) .{ }^{20 \mathrm{f}}$ The alkoxocarbene exhibits the socalled anti-conformation, with the methyl group oriented towards the gold center, as observed before in other transition metal Fischer alkoxocarbene complexes. ${ }^{20 f, 23}$ The planar arrangement for the phenyl ring may indicate some involvement in the stabilization of the electrophilic carbene but this is lost in solution where free rotation of the ring occurs, as shown by its ${ }^{1} \mathrm{H}$ NMR pattern. a)

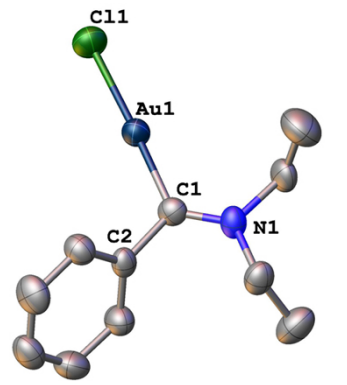

b)

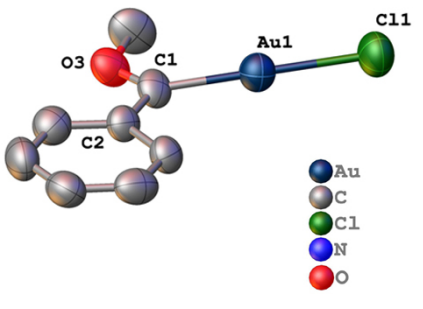

Figure 1. Molecular structures of complexes 2a (a) and 2b (b) (ORTEP plots $40 \%$ probability ellipsoids). Hydrogens have been omitted for clarity. Selected distances $(\AA)$ and angles $\left({ }^{\circ}\right)$ 2a: Au1-C1, 1.985(5); C1-N1, 1.295(6); Cl1-Au1-C1, 177.62(14); 2b: Au1-C1, 2.000(13); C1-O3, 1.277(13); C11-Au1-C1, 179.3(3).

The reaction of the neutral gold carbenes $\mathbf{2 a}$ and $\mathbf{2 b}$ with $\mathrm{AgSbF}_{6}$ in acetonitrile led to the complete conversion to the corresponding cationic $\mathrm{Au}(\mathrm{I})$ carbenes $\mathbf{3 a}$ and $\mathbf{3 b}$. Unfortunately, their isolation was not possible, but they were stable enough to be characterized by NMR. Even at low temperature, both complexes slowly evolve in acetonitrile solution to new species which were identified as the cationic $\mathrm{Au}(\mathrm{I})$ biscarbenes $\mathbf{4 a}$ and $\mathbf{4 b}$ (Scheme 2). A faster reaction rate for the rearrangement to the bisalkoxocarbene was observed compared to the amino analogue. The identity of the $\mathrm{Au}(\mathrm{I})$ biscarbenes was supported by reaction of different amounts of the tungsten monoaminocarbene 1a with one equivalent of the cationic $\mathrm{Au}(\mathrm{I})$ complex $\left[\mathrm{Au}(\mathrm{MeCN})_{2}\right] \mathrm{BF}_{4}$. When the reaction was carried out using an equimolar amount of $\mathrm{Au}$ and $\mathrm{W}$ complexes, both mono- and bis-carbenes were formed (100\% conversion of 1a, 3a:4a $=5: 1$ molar ratio after $10 \mathrm{~min}$ in solution at $25^{\circ} \mathrm{C}$ ). On the other hand, only the biscarbene complex $4 \mathbf{a}$ was formed by the addition of two equivalents of 1a (Scheme 2). The ${ }^{13} \mathrm{C} N M R$ reveals significant shifts in the carbenic carbon signals depending on the other ligand coordinated to the gold center and thus, when compared to the chloro (2) or acetonitrile (3) derivatives, the higher trans influence of the carbene fragment (4) is patent in the higher downfield shift observed (Schemes 1 and 2).

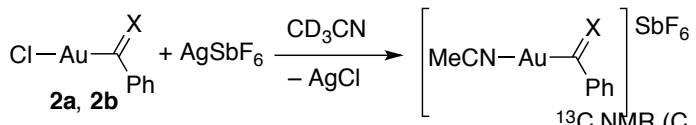

$$
\begin{aligned}
& \text { a, } \mathrm{X}=\mathrm{NEt}_{2} \\
& \text { b, } \mathrm{X}=\mathrm{OMe} \quad-\left[\mathrm{Au}(\mathrm{MeCN})_{2}\right] \mathrm{SbF}_{6} \quad \begin{array}{ll}
\text { 3a } & 265
\end{array} \\
& { }^{13} \mathrm{C} \text { NMR }\left(\mathrm{C}_{\text {carb }}, \delta\right)
\end{aligned}
$$

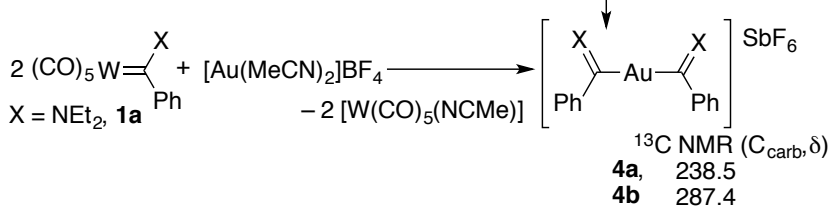

Scheme 2: Formation of cationic gold carbene derivatives.

The formation of the bis carbene complexes was also observed by the transmetalation of the alkoxocarbene from $\mathbf{1 b}$ to the cationic gold(I) aminocarbene 3a (generated in situ from 2a as shown in Scheme 2). The reaction involves the exchange of both carbene fragments and a mixture of the homoleptic biscarbenes $\mathbf{4 a}, \mathbf{4 b}$ was observed along with the new mixed complex $\mathbf{5}$, bearing two different carbene moieties.

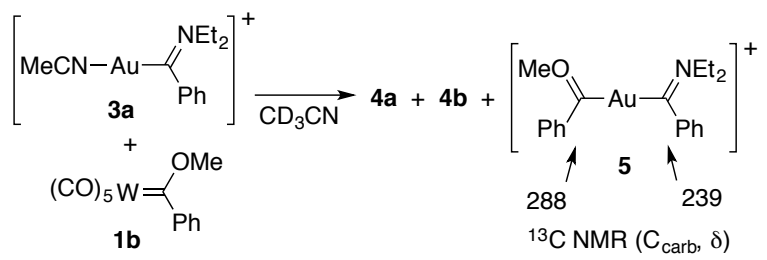

The reactivity of the neutral $\mathrm{Au}(\mathrm{I})$ monoamino- and alkoxocarbenes in the presence of acids or bases was studied (Eq. 3). Table 1 collects the phenyl-containing products formed, which give a complete account of the fate of the carbene fragment; the concomitant formation of other byproducts such as methanol of diethylamino derivatives also occurs (see below). $2 \mathbf{a}$ is stable in solution and remains unchanged for days at $50{ }^{\circ} \mathrm{C}$ (entry 1 , Table 1). No trace of hydrolysis products was detected even in the presence of water when heated at $50{ }^{\circ} \mathrm{C}$ (entry 2, Table 1). The addition of $\mathrm{NBu}_{4} \mathrm{OH}$ to a solution of $\mathbf{2 a}$ in $\mathrm{CD}_{3} \mathrm{CN}$ led to the formation of benzoate (6) (entry 3, Table 1). On the other hand, the gold(I) alkoxocarbene $\mathbf{2 b}$ is less stable and undergoes faster hydrolysis leading to methyl benzoate (7) benzaldehyde (8) and $\mathrm{MeOH}$ as products (entries 5-7, Table 1). It is worth noting, that a change in color of the solution from yellow to purple is usually observed with time, indicating the common decomposition to $\mathrm{Au}$ nanoparticles. The reactivity of the $\mathrm{Au}(\mathrm{I})$ carbenes towards a strong Brønsted acid such as $\mathrm{HBF}_{4}$ was also explored, revealing that both alkoxo and amino carbenes lead to the corresponding cationic biscarbenes 4 (entries 4 and 8, Table 1) with little or no decomposition of the carbene fragment; the higher reactivity of the alkoxocarbene leads to a higher conversion and eventually to some methyl benzoate as byproduct. 


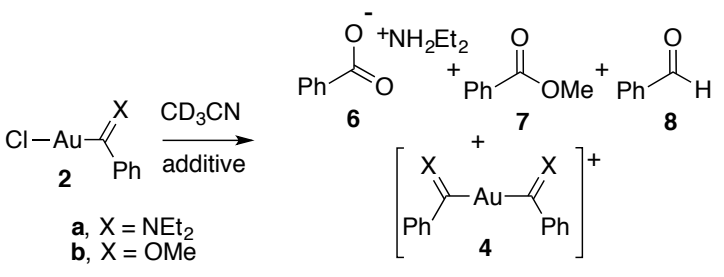

Table 1. Hydrolysis reactions of gold carbenes. ${ }^{\text {a }}$

\begin{tabular}{lllllllc} 
Entry & {$[\mathrm{Au}]$} & Additive & Conditions & $\mathbf{6}$ & $\mathbf{7}$ & $\mathbf{8}$ & $\mathbf{4}$ \\
1 & $\mathbf{2 a}$ & & Days $50{ }^{\circ} \mathrm{C}$ & & & \\
2 & $\mathbf{2 a}$ & $\mathrm{H}_{2} \mathrm{O}^{\mathrm{b}}$ & Days $50{ }^{\circ} \mathrm{C}$ & & & \\
3 & $\mathbf{2 a}$ & $\mathrm{NBu}_{4} \mathrm{OH}^{\mathrm{c}}$ & $1.5 \mathrm{~h}, 25{ }^{\circ} \mathrm{C}$ & $78 \%$ & & \\
4 & $\mathbf{2 a}$ & $\mathrm{HBF}_{4} \cdot \mathrm{OEt}_{2}$ & $24 \mathrm{~h}, 25{ }^{\circ} \mathrm{C}$ & & & $19 \%$ \\
5 & $\mathbf{2 b}$ & & $48 \mathrm{~h}, 25{ }^{\circ} \mathrm{C}$ & $5 \%$ & \\
6 & $\mathbf{2 b}$ & $\mathrm{H}_{2} \mathrm{O}^{\mathrm{b}}$ & $5 \mathrm{~min}, 25{ }^{\circ} \mathrm{C}$ & $15 \%$ & $64 \%$ & \\
7 & $\mathbf{2 b}$ & $\mathrm{NBu}_{4} \mathrm{OH}^{\mathrm{c}}$ & $1.5 \mathrm{~h}, 25{ }^{\circ} \mathrm{C}$ & $80 \%$ & \\
8 & $\mathbf{2 b}$ & $\mathrm{HBF}_{4} \cdot \mathrm{OEt}_{2}$ & $24 \mathrm{~h}, 25{ }^{\circ} \mathrm{C}$ & $24 \%$ & $59 \%$ \\
\hline
\end{tabular}

a) Reaction conditions: $0.014 \mathrm{mmol}$ of 2 in $0.6 \mathrm{~mL}$ of $\mathrm{CD}_{3} \mathrm{CN}$, $0.014 \mathrm{mmol}$ of additive; conversions were determined by ${ }^{1} \mathrm{H} \mathrm{NMR}$ b) Addition of two drops of water. c) Solution in $\mathrm{MeOH}$.

These reactions show the electrophilic character of the carbene carbon in these gold complexes, more pronounced for the alkoxocarbene than the aminocarbene. The hydrolysis of Fischer carbenes is well documented in other transition metal carbenes and the mechanism for the hydrolysis of group 6 metal carbenes was deeply studied by Bernasconi et al. and others. ${ }^{24}$ The results described in Table 1 suggest that a similar mechanism may operate for the electrophilic $\mathrm{Au}(\mathrm{I})$ Fischer carbenes. The reaction is believed to proceed in two stages involving a tetrahedral intermediate (A, Scheme 3 ) as a result of a nucleophilic attack on the carbenic carbon. At this point, two different pathways are possible according to the concentration of $\mathrm{OH}^{-}$. At low concentrations, the elimination of HX and the formation of the $\mathrm{Au}(\mathrm{I})$ acyl is faster than a second nucleophilic attack. ${ }^{25}$ The subsequent hydrolysis with water provokes the demetalation leading to benzaldehyde (8). At higher $\mathrm{OH}^{-}$concentrations, the second nucleophilic attack on the former carbenic carbon is favored, resulting in the formation of the gem diol $\mathbf{B}$ (Scheme 3). According to the nature of the substituent, when $\mathrm{X}=\mathrm{OMe}$, the elimination of water occurs leading to methyl benzoate (7) while the formation of the carboxylate 6 indicates the elimination of HX as observed if $\mathrm{X}=\mathrm{NEt}_{2}$.

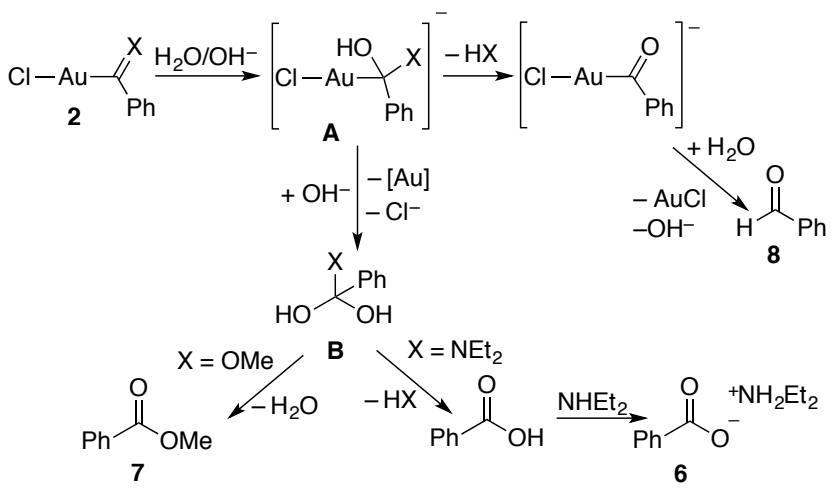

Scheme 3. Hydrolysis processes for gold carbenes $2 .^{26}$

Reactions of tungsten carbenes with $\mathrm{Ag}$ and $\mathrm{Cu}$ derivatives. A new carbene was detected during the reaction of the tungsten aminocarbene 1a with $[\mathrm{CuCl}(\mathrm{tht})]$ in acetonitrile at room temperature (Scheme 4). The slow transmetalation $(10 \%$ in $24 \mathrm{~h}$ at room temperature) prevented the isolation of the copper(I) carbene. Only a maximum conversion of $50 \%$ to 9 was achieved heating at $50{ }^{\circ} \mathrm{C}$ due to its competing decomposition to benzaldehyde $(\mathbf{8}, 25 \%)$ and $\mathrm{NHEt}_{2}$ in these conditions (entry 2, Table 2). NMR characterization of the 9 revealed a ${ }^{13} \mathrm{C}$ shift at $239.8 \mathrm{ppm}, 16 \mathrm{ppm}$ deshielded when compared to the analogous neutral gold(I) carbene $\mathbf{2 a}(224 \mathrm{ppm})$. Attempts to isolate $\mathbf{9}$ or to obtain suitable crystals for X-Ray diffraction from the reaction mixture failed, and the two-coordinated $\mathrm{Cu}(\mathrm{I})$ complex represented in Scheme 4 is tentative. DFT calculations show that the formation of 9 and $\left[\mathrm{W}\left(\mathrm{CO}_{5}(\right.\right.$ tht $\left.)\right]$ is thermodynamically favored and the associated free energy for the process is very similar for the two-, three- or four coordinated $\mathrm{Cu}(\mathrm{I})$ complexes $\left[\mathrm{CuCl}(\right.$ carbene $\left.)(\mathrm{MeCN})_{\mathrm{n}}\right](\mathrm{n}=0,1,2 ; \Delta \mathrm{G}=-6,-6.4,-7.5 \mathrm{kcal}$ $\mathrm{mol}^{-1}$ respectively, see Table S4 in the SI). Therefore, the formation of solvento three or four coordinated complexes, most probably in equilibrium with the dicoordinated complex in acetonitrile solution, cannot be ruled out. The lability of the ligands in three coordinated cationic copper carbene complexes has been studied before. ${ }^{27}$

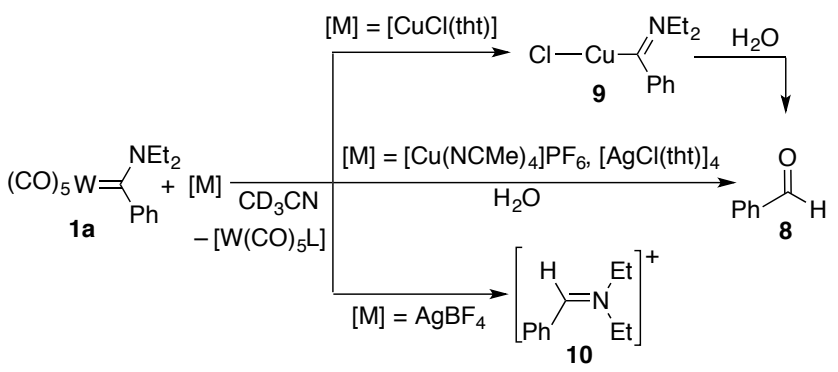

Scheme 4. Reactions of $\mathrm{Cu}$ and Ag complexes with 1a.

Table 2. Reactions of carbenes 1 with $\mathrm{Cu}$ and Ag complexes.

\begin{tabular}{|c|c|c|c|c|c|c|c|c|}
\hline Entry & {$[\mathrm{W}]$} & {$[\mathrm{M}]$} & Time & M-carb & 7 & 8 & 10 & 11 \\
\hline 1 & 1a & & days & & & $15 \%$ & & \\
\hline 2 & $1 \mathbf{a}$ & {$[\mathrm{CuCl}(\mathrm{tht})]$} & $4 \mathrm{~h}$ & $50 \%(9)$ & & $25 \%$ & & \\
\hline 3 & $1 \mathrm{a}$ & {$\left[\mathrm{Cu}(\mathrm{MeCN})_{4}\right] \mathrm{PF}_{6}$} & $624 \mathrm{~h}$ & & & $51 \%$ & & \\
\hline $4^{b}$ & $1 \mathrm{a}$ & $1 / 4[\mathrm{AgCl}(\mathrm{tht})]_{4}$ & $24 \mathrm{~h}$ & & & $13 \%$ & & \\
\hline 5 & $1 \mathrm{a}$ & $\mathrm{AgBF}_{4}$ & $24 \mathrm{~h}$ & & & & $72 \%$ & \\
\hline 6 & $1 \mathrm{~b}$ & & $24 \mathrm{~h}$ & & $5 \%$ & $13 \%$ & & \\
\hline 7 & $1 \mathbf{b}$ & {$[\mathrm{CuCl}($ tht $)]$} & $24 \mathrm{~h}$ & & $19 \%$ & $4 \%$ & & $77 \%$ \\
\hline 8 & $1 \mathrm{~b}$ & {$\left[\mathrm{Cu}(\mathrm{MeCN})_{4}\right] \mathrm{PF}_{6}$} & $63 \mathrm{~h}$ & & $24 \%$ & $66 \%$ & & \\
\hline $9^{b}$ & $1 b$ & $1 / 4[\mathrm{AgCl}(\mathrm{tht})]_{4}$ & $24 \mathrm{~h}$ & & $2 \%$ & $22 \%$ & & \\
\hline 10 & $1 b$ & $\mathrm{AgBF}_{4}$ & $30 \mathrm{~h}$ & & $9 \%$ & $18 \%$ & & \\
\hline
\end{tabular}

a) Reaction conditions: $0.022 \mathrm{mmol}$ of $1 \mathrm{a}$ and $0.022 \mathrm{mmol}$ of [M] in $0.6 \mathrm{~mL}$ of $\mathrm{CD}_{3} \mathrm{CN}$ at $50{ }^{\circ} \mathrm{C}$. Conversions were determined by ${ }^{1} \mathrm{H}$ NMR. b) Same results were obtained using $[\mathrm{AgBr}(\mathrm{tht})]_{4}$.

The reaction of $\mathbf{1 a}$ with $\left[\mathrm{Cu}(\mathrm{MeCN})_{4}\right] \mathrm{PF}_{6}$ led to hydrolysis products (Scheme 4 and entry 3, Table 2) with no detection of a cationic $\mathrm{Cu}(\mathrm{I})$ carbene intermediate. Similarly, no trace of new carbenes was observed when the tungsten alkoxocarbene $\mathbf{1 b}$ was reacted with $\mathrm{Cu}(\mathrm{I})$ complexes (Eq. 4). The addition of $\left[\mathrm{Cu}(\mathrm{MeCN})_{4}\right] \mathrm{PF}_{6}$ leads to decomposition to the hydrolysis products, by the same routes depicted in Scheme 3. The carbene dimerization derivative 11 (mixture of cis and trans isomers) was obtained as the major product if $[\mathrm{ClCu}(\mathrm{tht})]$ was used (Eq. 4 and 
entries 7 and 8, Table 2). It is known that some $\mathrm{Cu}$ complexes, ${ }^{18 \mathrm{~b}, 19,28}$ as well as other transition metal derivatives, ${ }^{18 a, 29,30}$ promote this carbene homocoupling in good to excellent yields.

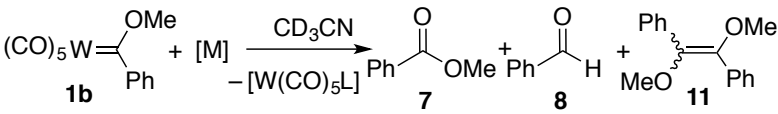

$$
\begin{aligned}
& {[\mathrm{M}]=[\mathrm{CuCl} \text { (tht) }],\left[\mathrm{Cu}(\mathrm{NCMe})_{4}\right] \mathrm{PF}_{6}, \mathrm{AgBF}_{4}}
\end{aligned}
$$

No trace of a new metal carbene complex was observed by direct transmetalation from the tungsten $(0)$ carbenes 1 to $[\mathrm{AgCl}($ tht $)]$ or $\mathrm{AgBF}_{4}$ in acetonitrile. Moreover, the decomposition data in Table 2 shows that the presence of $[\mathrm{AgCl}(\text { tht })]_{4}$ does not affect the decomposition rate of $\mathbf{1 a}$ (cf. entries 1 and 4, Table 2) and a similar behavior was observed for the reaction of either [AgCl(tht) $]_{4}$ or $\mathrm{AgBF}_{4}$ and $\mathbf{1 b}$ (cf. entries 6, 9 and 10, Table 2). In contrast, the presence of copper strongly affects the decomposition of the tungsten derivatives 1 (cf. entries 1-3 and 68 , Table 2) which points to the transfer of the carbene fragment to $\mathrm{Cu}$ (observed in the formation of $\mathbf{9}$ or undetected for other precursor complexes) and the lack of transmetalation for silver.

However, the reaction of $\mathbf{1 a}$ with $\mathrm{AgBF}_{4}$ revealed an interesting reactivity because of the unexpected formation of the iminium salt 10 when the mixture was heated at $50{ }^{\circ} \mathrm{C}$ in acetonitrile (Scheme 4 and entry 5, Table 2). Other silver salts AgY with weak coodinating anions led to the same product but, in general, proved to be less efficient in the decomposition of the carbene fragment. In the same conditions of entry 5, Table 2: AgOTf, 69\% 10, $\mathrm{AgSbF}_{6}, 45 \%$ 10; AgOTs, 34\% 10; AgTFA, 27\% 10 and $28 \% \mathbf{8}$ The formation of the iminium salt $\mathbf{1 0}$ from a metal carbene is a formal protonation of the carbene carbon, a very unusual reaction for the electrophilic Fischer carbenes involved in these reactions as will be discussed below.

\section{Comparison of the behavior of group $\mathbf{1 1}$ metals towards}

transmetalation. The experimental results described above indicate a clear trend in the ease of transmetalation from tungsten to group 11 metals: $\mathrm{Au}>\mathrm{Cu}>\mathrm{Ag}$. The same trend is observed in the thermodynamic parameters of the whole transmetalation processes, as shown in Eq. 5 and 6 , calculated by DFT and collected in Table 3 (see Experimental for details). The formation of the dicoordinated group 11 carbene complex was considered in all cases for comparison. Other coordination numbers were also explored in the reagents $\left(\left[\mathrm{M}\left(\mathrm{CH}_{3} \mathrm{CN}\right)_{n}\right]^{+}\right)$and products but the resulting energy values do not alter the observed trend (see above and Tables S4 and S5 in the SI). The transmetalation of the amino carbene group from complexes 1a to both neutral or cationic group 11 metal complexes is thermodynamically more favored than the transmetalation of the alkoxo carbene group from $\mathbf{1 b}$. For every combination of analogous reactants, the values in Table 3 show that, as far as thermodynamics is concerned, the ease of transmetalation follows the trend: $\mathrm{Au}>\mathrm{Cu}>\mathrm{Ag}$. These results are in agreement with the complete carbene transfer experimentally observed for gold in every case, whereas the formation of a copper carbene complex is observed in only one of the examples corresponding to the reaction in entry 1 , Table 3 . Nonetheless, the more reluctant formation of carbene $9(\mathrm{M}=\mathrm{Cu}$, $10 \%$ in $24 \mathrm{~h})$ when compared to $2 \mathrm{a}(\mathrm{M}=\mathrm{Au}$, complete conversion in $30 \mathrm{~min}$ ) must have a kinetic origin since the free energy values for both reactions are not too far apart (entries 1 and 3, Table 3). No silver carbene was detected and, as shown in Table 2 (entries 4, 9 and 10), the extent and rate of decomposition of the starting tungsten carbenes do not indicate the intermediacy of a more reactive metal carbene. One exception is the reaction of
$\mathrm{AgBF}_{4}$ with 1a (entry 5, Table 2), which shows a distinct and faster decomposition pattern and corresponds to the energetically most favorable transmetalation process calculated for silver (entry 8, Table 3).

$$
\begin{aligned}
& \underset{\mathbf{1 a}, \mathbf{b}}{(\mathrm{CO})_{5} \mathrm{Wh}}=\underset{\mathrm{Ph}}{\mathrm{X}}+[\mathrm{MCl}(\mathrm{tht})] \frac{\mathrm{MeCN}}{298 \mathrm{~K}} \mathrm{Cl}-\mathrm{M} \underset{\mathrm{Ph}}{\mathrm{K}}+\left[\mathrm{W}(\mathrm{CO})_{5}(\text { tht })\right] \\
& \underset{\mathbf{1}, \mathbf{b}}{(\mathrm{CO})_{5} \mathrm{~W}} \underset{\mathrm{Ph}}{\mathrm{X}}+\left[\mathrm{M}(\mathrm{MeCN})_{2}\right]^{+} \frac{\mathrm{MeCN}}{298 \mathrm{~K}}[\mathrm{MeCN}-\mathrm{M}-\underset{\mathrm{Ph}}{\longrightarrow}]^{\mathrm{X}}+\left[\mathrm{W}(\mathrm{CO})_{5}(\mathrm{MeCN})\right](6)
\end{aligned}
$$

Table 3. Calculated free energies for the formation of the group 11 metal carbenes. ${ }^{a}$

$\begin{array}{lllll}\text { Entry } & \mathrm{X} & {[\mathrm{M}]} & \Delta \mathrm{G}\left(\mathrm{kcal} \mathrm{mol}^{-1}\right) & \mathrm{M}^{-\mathrm{carb}^{\mathrm{b}}} \\ 1 & \mathrm{NEt}_{2} & {[\mathrm{CuCl}(\text { tht })]} & -6 & \mathbf{9} \\ 2 & \mathrm{NEt}_{2} & {[\mathrm{AgCl}(\text { tht })]} & -0.23 & - \\ 3 & \mathrm{NEt}_{2} & {[\mathrm{AuCl}(\text { tht })]} & -9.3 & \mathbf{2 a} \\ 4 & \mathrm{OMe} & {[\mathrm{CuCl}(\text { tht })]} & +1 & - \\ 5 & \mathrm{OMe} & {[\mathrm{AgCl}(\text { tht })]} & +7.4 & - \\ 6 & \mathrm{OMe} & {[\mathrm{AuCl}(\text { tht })]} & -2.9 & \mathbf{2 b} \\ 7 & \mathrm{NEt}_{2} & {\left[\mathrm{Cu}(\mathrm{NCMe})_{2}\right]^{+}} & -3.9 & - \\ 8 & \mathrm{NEt}_{2} & {\left[\mathrm{Ag}(\mathrm{NCMe})_{2}\right]^{+}} & -2.1 & - \\ 9 & \mathrm{NEt}_{2} & {\left[\mathrm{Au}(\mathrm{NCMe})_{2}\right]^{+}} & -16.3 & \mathbf{3 a} \\ 10 & \mathrm{OMe} & {\left[\mathrm{Cu}(\mathrm{NCMe})_{2}\right]^{+}} & +4.3 & - \\ 11 & \mathrm{OMe}_{12} & {\left[\mathrm{Ag}(\mathrm{NCMe})_{2}\right]^{+}} & +5.3 & - \\ 12 & \mathrm{OMe} & {\left[\mathrm{Au}(\mathrm{NCMe})_{2}\right]^{+}} & -9.2 & \mathbf{3 b}\end{array}$

a) DFT calculations according to Eq. 5 and 6 . b) Isolated (2) or characterized in solution $(\mathbf{3}, \mathbf{9})$

Heterobimetallic intermediates with bridging carbenes have been experimentally detected and/or isolated by Fürstner et al. during the transmetalation of chromium or tungsten carbenes to gold, ${ }^{13 \mathrm{~b}, 20 \mathrm{~d}}$ and calculated by Sierra et al. for the transmetalation of carbene fragments from chromium to palladium, copper or rhodium. $^{18 \mathrm{~b}}$ Thus, we decided to calculate the analogous heterobimetallic intermediates for the transmetalation of 1a to $\left[\mathrm{M}\left(\mathrm{CH}_{3} \mathrm{CN}\right)_{2}\right]^{+}$, where $\mathrm{M}=\mathrm{Ag}$, Au. This is the process that shows the lowest free energy among those transmetalations that involve silver and also a distinct reactivity pattern. The reactivity observed for the carbene fragment could derive from a complete transfer of the carbene to silver or from an arrested transmetalation to give a bimetallic intermediate with a bridging carbene. The intermediates 1a-M $(\mathbf{M}=\mathrm{Ag}, \mathrm{Au})$ depicted in Figure 1 were found, where $M$ interacts with the carbenic carbon and one of the carbonyl groups of the tungsten center. The $\mathrm{Au}-$ $\mathrm{C}_{\text {carbene }}$ distance in the calculated 1a-Au $(2.784 \AA)$ is longer than the $\mathrm{Au}-\mathrm{CO}$ one $(2.245 \AA)$ indicating an important interaction of the gold center with one of the carbonyl groups. When compared with this derivative, the intermediate $\mathbf{1 a - A g}$ shows similar distances between the metal and both fragments $\left(\mathrm{Ag}-\mathrm{C}_{\text {carbene }}\right.$, $2.594 \AA ; \mathrm{Ag}-\mathrm{C}(\mathrm{O}), 2.544 \AA)$. The calculated energy values for 1a-M $(M=A u, A g)$ are not very different but suggest again that the transmetalation of the tungsten monoaminocarbene to silver is less favored compared to gold since the silver heterobimetallic intermediate is about $3 \mathrm{kcal} \mathrm{mol}^{-1}$ higher in energy than the gold analogue. ${ }^{31}$ 


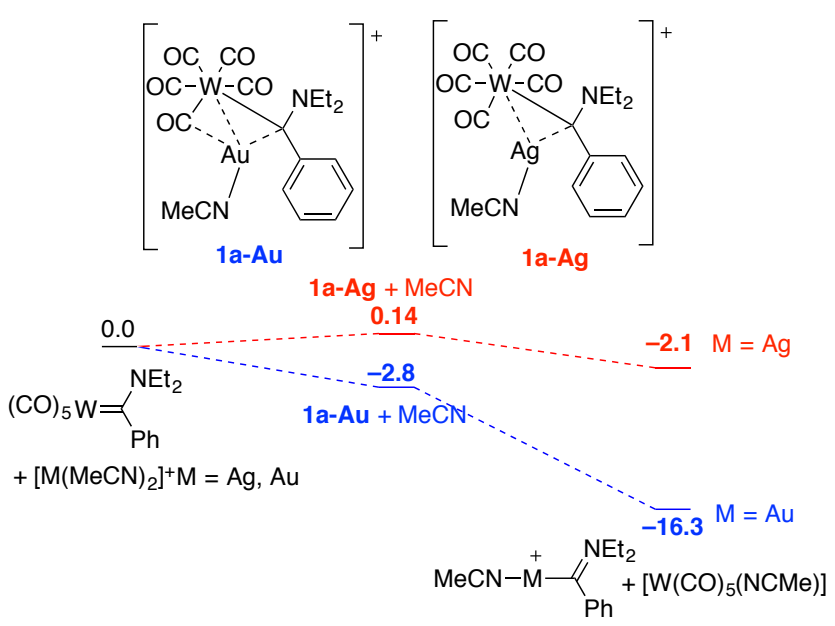

Figure 2. Calculated bimetallic intermediates in the transmetalation pathway $\left(\Delta \mathrm{G}, \mathrm{kcal} \mathrm{mol}^{-1}\right)$.

\section{Electrophilic character of the group 11 metal carbenes} and the role of silver in the formation of the iminium salt

10. The hydrolysis products observed for the gold carbenes or the reactions of the copper derivatives with $\mathbf{1}$ are consistent with the expected reactivity of an electrophilic carbene, i.e. a carbene fragment bound to a late transition metal fragment with no or very weak back donation ability. We calculated the three analogous cationic metal carbenes $\left[\mathrm{M}\left\{\mathrm{CPh}\left(\mathrm{NEt}_{2}\right)\right\}(\mathrm{NCMe})\right]^{+}(\mathrm{M}=\mathrm{Cu}, \mathrm{Ag}$, $\mathrm{Au}$ (3a)) and, indeed, the frontier orbitals for all three metal carbenes show similar electron distribution. However the decomposition of $\mathbf{1 a}$ in the presence of $\mathrm{AgBF}_{4}$ leads cleanly to the iminium salt 10, which is formally the result of the carbene protonation, a reaction pathway unexpected for a putative silver carbene. The generation of a free carbene by dissociation from silver could produce a nucleophilic center amenable to protonation. However a less selective reaction should be expected from such reactive species and DFT calculations show a high dissociation energy, not very different from the copper or tungsten carbenes which do not show that reactivity pattern in the same conditions (see SI, Table S6).

We carried out decomposition reactions of $\mathbf{1 a}$ in the presence and absence of $\mathrm{AgBF}_{4}$ in different conditions to corroborate that silver is playing a genuine role (Eq. 7 and Table 4). Despite the plausible presence of water due to the high hygroscopic character of the silver salt, this is not responsible of the reactivity observed by itself since no trace of the iminium salt was detected when water was deliberately added into a solution of $\mathbf{1 a}$ (entry 3, Table 4). Water does not accelerate the reaction in the presence of silver (entry 4, Table 4) and just an increase of the hydrolysis of the iminium salt to $\mathbf{8}$ was observed, as it was tested independently. When $\mathrm{D}_{2} \mathrm{O}$ was used the deuterated aldehyde 8-D was observed, indicating that the source of the proton in $\mathbf{1 0}$ is water. ${ }^{32}$ Only a couple of reports can be found in the literature describing the protonation of a tungsten carbene with $\mathrm{HCl}$ or $\mathrm{HBr}^{33}$ Indeed, the addition of $\mathrm{HBF}_{4} \mathrm{OEt}_{2}$ to complex 1a led to the iminium salt, a reaction that is still faster if $\mathrm{AgBF}_{4}$ is additionally present (cf. entries 5 and 6 , Table 4). According to this, the role of a metal cation could be to increase the acidity of the water present, by coordination, and therefore increase the decomposition rate. However, the Lewis acidic character of silver does not explain the formation of the iminium salt since no trace of $\mathbf{1 0}$ was observed when a Lewis acid of higher acidity such as $\mathrm{Zn}$ (II) was added, even in the presence of water (cf. entries 7, 8 and 9, Table 4). ${ }^{34}$

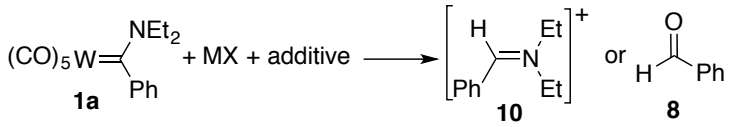

Table 4. Decomposition reactions of 1 a according to Eq. 7.

\begin{tabular}{llllll}
\hline Entry & $\mathrm{MX}$ & Additive & Conditions & $\mathbf{1 0}$ & $\mathbf{8}$ \\
\hline 1 & & & 6 days, $50{ }^{\circ} \mathrm{C}$ & & $15 \%$ \\
2 & $\mathrm{AgBF}_{4}$ & & $26 \mathrm{~h}, 50{ }^{\circ} \mathrm{C}$ & $72 \%$ & - \\
3 & & $\mathrm{H}_{2} \mathrm{O}^{\mathrm{b}}$ & $26 \mathrm{~h}, 50{ }^{\circ} \mathrm{C}$ & & $4 \%$ \\
4 & $\mathrm{AgBF}_{4}$ & $\mathrm{H}_{2} \mathrm{O}^{\mathrm{b}}$ & $20 \mathrm{~h} 50{ }^{\circ} \mathrm{C}$ & & $36 \%$ \\
5 & & $\mathrm{HBF}_{4}$ & $24 \mathrm{~h}, 25{ }^{\circ} \mathrm{C}$ & $67 \%$ & \\
6 & $\mathrm{AgBF}_{4}$ & $\mathrm{HBF}_{4}$ & $5 \mathrm{~h}, 50{ }^{\circ} \mathrm{C}$ & $90 \%$ & \\
7 & $\mathrm{ZnCl}_{2}$ & & $24 \mathrm{~h}, 50{ }^{\circ} \mathrm{C}$ & & $17 \%$ \\
8 & ${\mathrm{Zn}(\mathrm{OTf})_{2}}$ & & $20 \mathrm{~h}, 50{ }^{\circ} \mathrm{C}$ & & $9 \%$ \\
9 & $\mathrm{AgOTf}$ & & $24 \mathrm{~h}, 50{ }^{\circ} \mathrm{C}$ & $69 \%$ &
\end{tabular}

a) Reaction conditions: $0.022 \mathrm{mmol}$ of $1 \mathrm{a}, 0.022 \mathrm{mmol}$ of $\mathrm{AgBF}_{4}$ or zinc salts and $0.022 \mathrm{mmol}$ of additive in $0.6 \mathrm{~mL}$ of $\mathrm{CD}_{3} \mathrm{CN}$; conversions were determined by ${ }^{1} \mathrm{H}$ NMR; b) Two drops of water.

These experiments show that silver is important to trigger the decomposition observed. Since the carbene transmetalation from 1a to a cationic acetonitrile silver complex is the thermodynamically most favored process for this metal, according to the data in Table 3, we explored the possibility of the protonation of the putative silver carbene $\left[\mathrm{Ag}\left\{\mathrm{CPh}\left(\mathrm{NEt}_{2}\right)\right\}(\mathrm{NCMe})\right]^{+}$(c1) by water. An energetically accessible pathway was found through a transition state that involves the simultaneous interaction of water with silver and the carbene carbon (Figure 3 ). The process has an activation energy of $25.3 \mathrm{kcal} \mathrm{mol}^{-1}$ which could be overcome in the reaction conditions used: the formation of the iminum salt is a slow reaction that requires heating for hours. The products formed from TS1, 10 and $\mathrm{Ag}(\mathrm{OH}) \mathrm{NCMe}$, are not very stable but the evolution of the silver species to the insoluble silver oxide can provide the thermodynamic drive of the process.

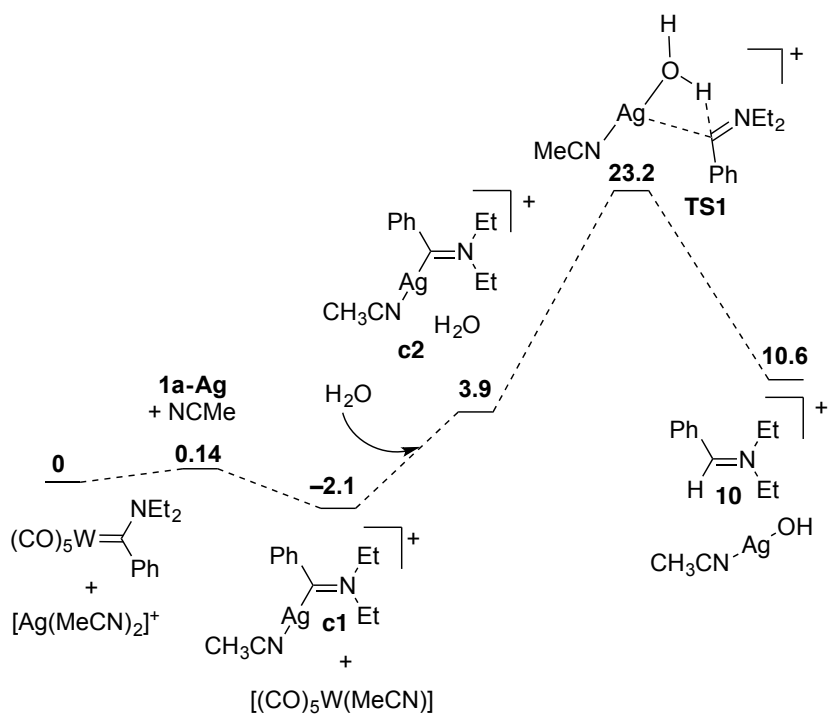

Figure 3. Free energy profile for the protonation of a silver carbene by water. Energies in $\mathrm{kcal} \mathrm{mol}^{-1}$.

This means that a nucleophillic behavior for silver carbenes might be possible. Furstner at al. have suggested this type of behavior for silver polymetalic complexes with bridging non-stabilized diarylcarbene fragments, recently disclosed by this group. ${ }^{35}$ 
According to this, we also explored if the interaction of water with bimetallic silver complexes could lead to the direct protonation of the bridging carbene. No intermediate was found from the interaction of $\mathrm{H}_{2} \mathrm{O}$ with the calculated bimetallic $\mathrm{Ag}-\mathrm{W}$ complex 1a-Ag (Figure 2). The calculated dimeric complex $\left[(\mathrm{MeCN}) \mathrm{Ag}\left\{\mu-\mathrm{CPh}\left(\mathrm{NEt}_{2}\right)\right\} \mathrm{Ag}(\mathrm{NCMe})\right]^{2+}$ evolves in the presence of a water molecule to the monomeric silver carbene $\left[\mathrm{Ag}\left\{\mathrm{CPh}\left(\mathrm{NEt}_{2}\right)\right\}(\mathrm{NCMe})\right]^{+}$and $\left[\mathrm{Ag}(\mathrm{NCMe})\left(\mathrm{H}_{2} \mathrm{O}\right)\right]^{+}$(see SI for details).

\section{CONCLUSION}

The reaction of tungsten $(0)$ Fischer carbenes with neutral and cationic complexes of the group 11 metals revealed different behavior for each metal. Direct transmetalation to gold occurs leading to the instantaneous formation of the carbene complexes and a series of neutral and cationic $A u(I)$ carbenes have been prepared and characterized. Transmetalation to $\mathrm{Cu}(\mathrm{I})$ may occur, but only one copper monoaminocarbene species has been detected during our studies due to their lower stability. No experimental evidence of the formation of silver carbenes was found. DFT calculations mirror the experimental results and show that the formation of group 11 carbenes by direct transmetalation of tungsten(0) Fischer carbenes is thermodynamically favored for gold(I), possible for copper(I) and endergonic for most silver(I) precursors.

The hydrolysis of the isolated gold carbenes reveals the typical behavior of an electrophilic metal carbene. The same type of reactivity is observed by the analysis of the carbene decomposition products in the reactions of the tungsten $(0)$ carbenes with copper complexes.

On the other hand, the presence of silver does not induce the decomposition of the tungsten methoxycarbene $\mathbf{1 b}$ in all cases or the monoamino carbene for the neutral silver precursors. This is an indirect indication that transmetalation of the carbene fragment to silver is not taking place. However, the reaction of the tungsten $(0)$ monoaminocarbene 1a with silver salts with weaklycoordinating anions, and specially $\mathrm{AgBF}_{4}$ in acetonitrile, leads to an unprecedent carbene demetalation reaction by formation of an iminium salt. This is a formal protonation of the carbene acting as a nucleophillic center. The transmetalation of the carbene from $\mathbf{1 a}$ to a silver acetonitrile complex is thermodynamically favored and we found by DFT calculations that the protonation of the resulting putative cationic silver carbene with water is possible, although energetically demanding. This shows a distinct behavior for silver among group 11 metals and the possibility of a mirror reactivity (carbene as a nucleophile) for the elusive silver complexes with less stabilized carbenes.

\section{EXPERIMENTAL}

General Methods. ${ }^{1} \mathrm{H},{ }^{13} \mathrm{C}\left\{{ }^{1} \mathrm{H}\right\}$, and ${ }^{31} \mathrm{P}\left\{{ }^{1} \mathrm{H}\right\}$ NMR spectra were recorded on Bruker AV-400, Varian MR400 or Varian Inova 500 spectrometers (LTI-UVa). Chemical shifts (in $\delta$ units, ppm) were referenced to $\mathrm{SiMe}_{4}\left({ }^{1} \mathrm{H}\right.$ and $\left.{ }^{13} \mathrm{C}\right)$ and $\mathrm{H}_{3} \mathrm{PO}_{4}\left(85 \%,{ }^{31} \mathrm{P}\right)$. The spectral data were recorded at $293 \mathrm{~K}$ unless otherwise noted. Heteronuclear ${ }^{1} \mathrm{H}-{ }^{13} \mathrm{C}$ HSQC and HMBC experiments were used to help with the signal assignments. All reactions were carried out under an atmosphere of $\mathrm{N}_{2}$. Tungsten carbenes $\mathbf{1 a}^{36}$ and $\mathbf{1 b}{ }^{37}$ $[\mathrm{AuCl}(\mathrm{tht})],{ }^{38} \quad\left[\mathrm{Au}\left(\mathrm{CH}_{3} \mathrm{CN}\right)_{2}\right] \mathrm{BF}_{4},{ }^{39} \quad\left[\mathrm{Cu}\left(\mathrm{CH}_{3} \mathrm{CN}\right)_{4}\right] \mathrm{PF}_{6},{ }^{40}$ $[\mathrm{CuCl}($ tht $)],{ }^{41}[\mathrm{AgBr}(\mathrm{tht})]_{4}$ and $[\mathrm{AgCl}(\text { tht })]_{4},{ }^{42}$ were synthetized according to the literature methods. Solvents were dried using an SPS PS-MD-5 solvent purification system prior to use. Silver salts, tetrabutylammonium hydroxide ( $1 \mathrm{M}$ solution in $\mathrm{MeOH})$ tetrafluoroboric acid etherate, zinc chloride and zinc triflate, are commercially available and were purchased from commercial sources. The reactions using the light sensitive silver compounds were carried out in the absence of light.

Synthesis of 2a. [AuCl(tht)] $(0.26 \mathrm{~g}, 0.83 \mathrm{mmol})$ was added to a solution of the tungsten carbene $1 \mathrm{a}(0.4 \mathrm{~g}, 0.83 \mathrm{mmol})$ in $30 \mathrm{~mL}$ of $\mathrm{CH}_{2} \mathrm{Cl}_{2}$. The yellow solution was stirred for 20 minutes and filtered through celite and activated carbon. The solvent was evaporated to c.a. $2 \mathrm{~mL}$ and pentane $(5 \mathrm{~mL})$ was added. The yellow solid was filtered, recrystallized in $\mathrm{CH}_{2} \mathrm{Cl}_{2} /$ pentane and dried in vacuum $(0.28 \mathrm{~g} ; 86 \%$ yield $) .{ }^{1} \mathrm{H}$ NMR $(400 \mathrm{MHz}, \delta$, $\left.\mathrm{CD}_{3} \mathrm{CN}\right): 7.47\left(\mathrm{~m}, 2 \mathrm{H}, \mathrm{H}_{\text {meta }}\right), 7.36\left(\mathrm{~m}, 1 \mathrm{H}, \mathrm{H}_{\text {para }}\right), 7.09(\mathrm{~m}, 2 \mathrm{H}$, $\mathrm{H}_{\text {ortho }}$ ), 4.23 (q, $\left.J=7.25 \mathrm{~Hz}, 2 \mathrm{H}, \mathrm{CH}_{2} \mathrm{CH}_{3}\right), 3.53$ (q, $J=7.25 \mathrm{~Hz}$, $\left.2 \mathrm{H}, \mathrm{CH}_{2}{ }_{2} \mathrm{CH}_{3}\right), 1.55\left(\mathrm{t}, J=7.25 \mathrm{~Hz}, 3 \mathrm{H}, \mathrm{CH}_{2} \mathrm{CH}_{3}\right), 1.17(\mathrm{t}, J=$ $\left.7.25 \mathrm{~Hz}, 3 \mathrm{H}, \mathrm{CH}_{2} \mathrm{CH}_{3}{ }_{3}\right) .{ }^{13} \mathrm{C}\left\{{ }^{1} \mathrm{H}\right\} \quad \mathrm{NMR}(100.61 \mathrm{MHz}, \delta$, $\left.\mathrm{CD}_{3} \mathrm{CN}\right)$ : 223.8 ( $\left.\mathrm{C}_{\text {carbene }}\right), 144.7\left(\mathrm{C}_{\text {ipso }}\right), 129.9\left(\mathrm{C}_{\text {meta }}\right), 129.3$ $\left(\mathrm{C}_{\text {para }}\right), 123.8\left(\mathrm{C}_{\text {ortho }}\right), 57.9\left(\mathrm{CH}_{2} \mathrm{CH}_{3}\right), 49.2\left(\mathrm{C}^{\prime} \mathrm{H}_{2} \mathrm{CH}_{3}\right), 14.6$ $\left(\mathrm{CH}_{2} \mathrm{CH}_{3}\right), 13.9\left(\mathrm{CH}_{2} \mathrm{C}^{\prime} \mathrm{H}_{3}\right)$. Anal. Calcd. for $\mathrm{C}_{11} \mathrm{H}_{15} \mathrm{AuClN}$ : C, 33.56; H, 3.84; N, 3.56; Found: C, 33.66; H, 3.62; N, 3.50\%.

Synthesis of $\mathbf{2 b}$. This complex was synthesized using a similar procedure as described above for $\mathbf{2 a}$ but using the tungsten carbene 1b. Red solid ( $0.26 \mathrm{~g} ; 88 \%$ yield). ${ }^{1} \mathrm{H}$ NMR $(400 \mathrm{MHz}, \delta$, $\left.\mathrm{CD}_{3} \mathrm{CN}\right): 8.35\left(\mathrm{~m}, 2 \mathrm{H}, \mathrm{H}_{\text {ortho }}\right), 7.88\left(\mathrm{~m}, 1 \mathrm{H}, \mathrm{H}_{\text {para }}\right), 7.62(\mathrm{~m}, 2 \mathrm{H}$, $\mathrm{H}_{\text {meta }}$ ), $4.94\left(\mathrm{~s}, 3 \mathrm{H}, \mathrm{OCH}_{3}\right) \cdot{ }^{13} \mathrm{C}\left\{{ }^{1} \mathrm{H}\right\} \mathrm{NMR}(100.61 \mathrm{MHz}, \delta$, $\left.\mathrm{CD}_{3} \mathrm{CN}\right): 267.9\left(\mathrm{C}_{\text {carbene }}\right), 143.2\left(\mathrm{C}_{\text {ipso }}\right), 139.4\left(\mathrm{C}_{\text {para }}\right), 136.0$ $\left(\mathrm{C}_{\text {ortho }}\right), 130.5\left(\mathrm{C}_{\text {meta }}\right), 72.6\left(\mathrm{OCH}_{3}\right)$. Anal. Calcd. for $\mathrm{C}_{8} \mathrm{H}_{8} \mathrm{AuClO}$ : C, 27.26; H, 2.29; Found: C, 27.33; H, 2.32.

Characterization of 3a and 4a. A vial was charged with $\mathrm{AgSbF}_{6}$ $(0.04 \mathrm{~g}, 0.116 \mathrm{mmol})$ and a solution of $2 \mathrm{a}(0.03 \mathrm{~g}, 0.076 \mathrm{mmol})$ in $0.6 \mathrm{~mL}$ of $\mathrm{CD}_{3} \mathrm{CN}$ was added under an atmosphere of nitrogen at $243 \mathrm{~K}$. The grey suspension was warmed up to room temperature for $30 \mathrm{~min}$ and filtered through a pad of celite. The colourless solution, containing complexes 3a:4a $=20: 1$ mol ratio was introduced in a $5 \mathrm{~mm}$ NMR tube characterized by NMR. 3a: ${ }^{1} \mathrm{H}$ NMR (400 MHz, $\left.\delta, \mathrm{CD}_{3} \mathrm{CN}, 243 \mathrm{~K}\right): 7.51$ (m, 2H, $\left.\mathrm{H}_{\text {meta }}\right), 7.41$ $\left(\mathrm{m}, 1 \mathrm{H}, \mathrm{H}_{\text {para }}\right), 7.12\left(\mathrm{~m}, 2 \mathrm{H}, \mathrm{H}_{\text {ortho }}\right), 4.22(\mathrm{q}, J=7.33 \mathrm{~Hz}, 2 \mathrm{H}$, $\left.\mathrm{CH}_{2} \mathrm{CH}_{3}\right), 3.62\left(\mathrm{q}, J=7.33 \mathrm{~Hz}, 2 \mathrm{H}, \mathrm{CH}^{\prime}{ }_{2} \mathrm{CH}_{3}\right), 1.55(\mathrm{t}, J=7.33$ $\left.\mathrm{Hz}, 3 \mathrm{H}, \mathrm{CH}_{2} \mathrm{CH}_{3}\right), 1.19$ (t, $\left.J=7.33 \mathrm{~Hz}, 3 \mathrm{H}, \mathrm{CH}_{2} \mathrm{CH}^{\prime}{ }_{3}\right) .{ }^{13} \mathrm{C}\left\{{ }^{1} \mathrm{H}\right\}$ NMR (100.61 MHz, $\left.\left.\delta, \mathrm{CD}_{3} \mathrm{CN}, 243 \mathrm{~K}\right): 216.9 \mathrm{C}_{\text {carbene }}\right), 143.1$ $\left(\mathrm{C}_{\text {ipso }}\right), 130.1\left(\mathrm{C}_{\text {para }}\right), 130\left(\mathrm{C}_{\text {meta }}\right), 124.2\left(\mathrm{C}_{\text {ortho }}\right), 58.9\left(\mathrm{CH}_{2} \mathrm{CH}_{3}\right)$, $49.7\left(\mathrm{C}^{\prime} \mathrm{H}_{2} \mathrm{CH}_{3}\right), 14.9\left(\mathrm{CH}_{2} \mathrm{CH}_{3}\right), 14\left(\mathrm{CH}_{2} \mathrm{C}^{\prime} \mathrm{H}_{3}\right) .4 a:{ }^{1} \mathrm{H} \mathrm{NMR}$ $\left(400 \mathrm{MHz}, \delta, \mathrm{CD}_{3} \mathrm{CN}, 243 \mathrm{~K}\right): 7.46\left(\mathrm{~m}, 2 \mathrm{H}, \mathrm{H}_{\text {meta }}\right), 7.38(\mathrm{~m}, 1 \mathrm{H}$, $\left.\mathrm{H}_{\text {para }}\right), 7.05\left(\mathrm{~m}, 2 \mathrm{H}, \mathrm{H}_{\text {meta }}\right), 4.18\left(\mathrm{q}, J=7.31 \mathrm{~Hz}, 2 \mathrm{H}, \mathrm{CH}_{2} \mathrm{CH}_{3}\right)$, $3.57\left(\mathrm{q}, J=7.31 \mathrm{~Hz}, 2 \mathrm{H}, \mathrm{CH}^{\prime}{ }_{2} \mathrm{CH}_{3}\right), 1.52(\mathrm{t}, J=7.31 \mathrm{~Hz}, 3 \mathrm{H}$, $\mathrm{CH}_{2} \mathrm{CH}_{3}$ ), 1.17 (t, $\left.J=7.31 \mathrm{~Hz}, 3 \mathrm{H}, \mathrm{CH}_{2} \mathrm{C}^{3} \mathrm{H}_{3}\right) .{ }^{13} \mathrm{C}\left\{{ }^{1} \mathrm{H}\right\} \mathrm{NMR}$ $\left(100.61 \mathrm{MHz}, \delta, \mathrm{CD}_{3} \mathrm{CN}, 243 \mathrm{~K}\right): 239\left(\mathrm{C}_{\text {carbene }}\right), 143.7\left(\mathrm{C}_{\mathrm{ipso}}\right)$, $129.9\left(\mathrm{C}_{\text {para }}\right), 129.5\left(\mathrm{C}_{\text {meta }}\right), 123.9\left(\mathrm{C}_{\text {ortho }}\right), 57.5\left(\mathrm{CH}_{2} \mathrm{CH}_{3}\right), 49.7$ $\left(C^{\prime} \mathrm{H}_{2} \mathrm{CH}_{3}\right), 15.2\left(\mathrm{CH}_{2} \mathrm{CH}_{3}\right), 14.1\left(\mathrm{CH}_{2} \mathrm{C}^{\prime} \mathrm{H}_{3}\right)$.

Characterization of $\mathbf{3 b}$ and $\mathbf{4 b}$. A vial was charged with $\mathrm{AgSbF}_{6}$ $(0.03 \mathrm{~g}, 0.087 \mathrm{mmol})$ and a solution of $\mathbf{2 b}(0.02 \mathrm{~g}, 0.057 \mathrm{mmol})$ in $0.6 \mathrm{~mL}$ of $\mathrm{CD}_{3} \mathrm{CN}$ was added under an atmosphere of nitrogen at $243 \mathrm{~K}$ and stirred for $10 \mathrm{~min}$. The yellowish solution was transferred to a $5 \mathrm{~mm}$ NMR tube and the mixture $(\mathbf{3 b}: \mathbf{4 b}=10: 1$ mol ratio) characterized by NMR at $243 \mathrm{~K}$. 3b: ${ }^{1} \mathrm{H}$ NMR $(500$ $\left.\mathrm{MHz}, \delta, \mathrm{CD}_{3} \mathrm{CN}, 243 \mathrm{~K}\right): 8.31\left(\mathrm{~m}, 2 \mathrm{H}, \mathrm{H}_{\text {ortho }}\right), 7.92\left(\mathrm{~m}, 1 \mathrm{H}, \mathrm{H}_{\text {para }}\right)$, $7.64\left(\mathrm{~m}, 2 \mathrm{H}, \mathrm{H}_{\text {meta }}\right), 4.94\left(\mathrm{~s}, 3 \mathrm{H}, \mathrm{OCH}_{3}\right) .{ }^{13} \mathrm{C}\left\{{ }^{1} \mathrm{H}\right\}$ NMR $(125.76$ $\left.\mathrm{MHz}, \delta, \mathrm{CD}_{3} \mathrm{CN}, 243 \mathrm{~K}\right): 264.6\left(\mathrm{C}_{\text {carbene }}\right), 141.5\left(\mathrm{C}_{\mathrm{ppso}}\right), 140.2$ $\left(\mathrm{C}_{\text {para }}\right), 135.9\left(\mathrm{C}_{\text {ortho }}\right), 130.2\left(\mathrm{C}_{\text {meta }}\right), 73.4\left(\mathrm{OCH}_{3}\right) .4 \mathbf{b}:{ }^{1} \mathrm{H}$ NMR $\left(500 \mathrm{MHz}, \delta, \mathrm{CD}_{3} \mathrm{CN}, 243 \mathrm{~K}\right): 8.42\left(\mathrm{~m}, 2 \mathrm{H}, \mathrm{H}_{\text {ortho }}\right), 7.93(\mathrm{~m}, 1 \mathrm{H}$, $\left.\mathrm{H}_{\text {para }}\right), 7.70\left(\mathrm{~m}, 2 \mathrm{H}, \mathrm{H}_{\text {meta }}\right), 5.10\left(\mathrm{~s}, 3 \mathrm{H}, \mathrm{OCH}_{3}\right) .{ }^{13} \mathrm{C}\left\{{ }^{1} \mathrm{H}\right\} \mathrm{NMR}$ (125.76 MHz, $\left.\delta, \mathrm{CD}_{3} \mathrm{CN}, 243 \mathrm{~K}\right): 287.4$ ( $\left.\mathrm{C}_{\text {carbene }}\right), 142.2\left(\mathrm{C}_{\mathrm{ipso}}\right)$, $140\left(\mathrm{C}_{\text {para }}\right), 135.4\left(\mathrm{C}_{\text {ortho }}\right), 130.2\left(\mathrm{C}_{\text {meta }}\right), 72.2\left(\mathrm{OCH}_{3}\right)$.

Characterization of 5. A vial was charged with $\mathrm{AgSbF}_{6}(0.027 \mathrm{~g}$, $0.077 \mathrm{mmol})$ and a solution of $2 \mathrm{a}(0.02 \mathrm{~g}, 0.051 \mathrm{mmol})$ in $0.6 \mathrm{~mL}$ of $\mathrm{CD}_{3} \mathrm{CN}$ was added under an atmosphere of nitrogen at $-30{ }^{\circ} \mathrm{C}$. 
After 2 minutes, the tungsten carbene 1 b $(0.023 \mathrm{~g}, 0.051 \mathrm{mmol})$ was added to the mixture. The yellowish suspension was filtered, transferred to a $5 \mathrm{~mm}$ NMR tube and characterized by NMR at $293 \mathrm{~K}$. It contained a mixture of $\mathbf{4 a : 4 b : 5}=1.6: 1: 3.6$ mol ratio. $\mathbf{5}$ : ${ }^{1} \mathrm{H}$ NMR (400 MHz, $\left.\delta, \mathrm{CD}_{3} \mathrm{CN}\right): 8.32\left(\mathrm{~m}, 2 \mathrm{H}, \mathrm{H}_{\text {ortho }}^{\mathrm{b}}\right), 7.90(\mathrm{~m}$, $\left.1 \mathrm{H}, \mathrm{H}_{\text {para }}^{\mathrm{b}}\right), 7.67\left(\mathrm{~m}, 2 \mathrm{H}, \mathrm{H}^{\mathrm{b}}{ }_{\text {meta }}\right), 7.55\left(\mathrm{~m}, 2 \mathrm{H}, \mathrm{H}_{\text {meta }}^{\mathrm{a}}\right), 7.43(\mathrm{~m}$, $\left.1 \mathrm{H}, \mathrm{H}_{\text {para }}^{\mathrm{a}}\right), 7.23\left(\mathrm{~m}, 2 \mathrm{H}, \mathrm{H}_{\text {ortho }}^{\mathrm{a}}\right), 4.99\left(\mathrm{~s}, 3 \mathrm{H}, \mathrm{OCH}_{3}\right), 4.30(\mathrm{q}, J=$ $\left.7.32 \mathrm{~Hz}, 2 \mathrm{H}, \mathrm{CH}_{2} \mathrm{CH}_{3}\right), 3.68\left(\mathrm{q}, J=7.32 \mathrm{~Hz}, 2 \mathrm{H}, \mathrm{CH}_{2}{ }_{2} \mathrm{CH}_{3}\right)$, $1.62\left(\mathrm{t}, J=7.32 \mathrm{~Hz}, 3 \mathrm{H}, \mathrm{CH}_{2} \mathrm{CH}_{3}\right), 1.25(\mathrm{t}, J=7.32 \mathrm{~Hz}, 3 \mathrm{H}$, $\left.\mathrm{CH}_{2} \mathrm{CH}_{3}{ }_{3}\right) .{ }^{13} \mathrm{C}\left\{{ }^{1} \mathrm{H}\right\}$ NMR $\left(100.61 \mathrm{MHz}, \delta, \mathrm{CD}_{3} \mathrm{CN}\right): 288.8$ $\left(\mathrm{C}_{\text {carbene }}^{\mathrm{b}}\right), 239.1\left(\mathrm{C}_{\text {carbene }}^{\mathrm{a}}\right), 143.8\left(\mathrm{C}^{\mathrm{a}}{ }_{\text {ipso }}\right), 143.1\left(\mathrm{C}^{\mathrm{b}}{ }_{\text {ipso }}\right), 140.3$ $\left(\mathrm{C}_{\text {para }}^{\mathrm{b}}\right), 135.6\left(\mathrm{C}_{\text {ortho }}^{\mathrm{b}}\right), 130.7\left(\mathrm{C}_{\text {meta }}^{\mathrm{b}}\right), 130.2\left(\mathrm{C}_{\text {meta }}^{\mathrm{a}}\right), 130\left(\mathrm{C}_{\text {para }}^{\mathrm{a}}\right)$, $124.4\left(\mathrm{C}_{\text {ortho }}^{\mathrm{a}}\right), 72.5\left(\mathrm{OCH}_{3}\right), 57.8\left(\mathrm{CH}_{2} \mathrm{CH}_{3}\right), 50.1\left(\mathrm{C}^{\prime} \mathrm{H}_{2} \mathrm{CH}_{3}\right)$, $15.6\left(\mathrm{CH}_{2} \mathrm{CH}_{3}\right), 14.3\left(\mathrm{CH}_{2} \mathrm{C}^{\prime} \mathrm{H}_{3}\right)$.

Detection and characterization of 9. [CuCl(tht)] $(0.023 \mathrm{~g}, 0.123$ $\mathrm{mmol})$ was added under an atmosphere of nitrogen to a solution of $1 \mathrm{a}(0.015 \mathrm{~g}, 0.031 \mathrm{mmol})$ in $0.6 \mathrm{~mL}$ of $\mathrm{CD}_{3} \mathrm{CN}$. The yellowish solution was heated for $1 \mathrm{~h}$ at $50^{\circ} \mathrm{C}$ and characterized by NMR at $293 \mathrm{~K} .{ }^{1} \mathrm{H}$ NMR $\left(400 \mathrm{MHz}, \delta, \mathrm{CD}_{3} \mathrm{CN}\right): 7.43-7.32$ (m, 3H, $\mathrm{H}_{\text {meta }}$ $\left.+\mathrm{H}_{\text {para }}\right), 7.02\left(\mathrm{~m}, 2 \mathrm{H}, \mathrm{H}_{\text {ortho }}\right), 4.10\left(\mathrm{q}, J=7.23 \mathrm{~Hz}, 2 \mathrm{H}, \mathrm{CH}_{2} \mathrm{CH}_{3}\right)$, 3.50 (q, $\left.J=7.23 \mathrm{~Hz}, 2 \mathrm{H}, \mathrm{CH}_{2}{ }_{2} \mathrm{CH}_{3}\right), 1.52$ (t, $J=7.23 \mathrm{~Hz}, 3 \mathrm{H}$, $\mathrm{CH}_{2} \mathrm{CH}_{3}$ ), 1.17 (t, $\left.J=7.23 \mathrm{~Hz}, 3 \mathrm{H}, \mathrm{CH}_{2} \mathrm{CH}_{3}{ }_{3}\right) .{ }^{13} \mathrm{C}\left\{{ }^{1} \mathrm{H}\right\} \mathrm{NMR}$ $\left(100.61 \mathrm{MHz}, \delta, \mathrm{CD}_{3} \mathrm{CN}\right): 239.8\left(\mathrm{C}_{\text {carbene }}\right), 144.3\left(\mathrm{C}_{\mathrm{ipso}}\right), 128.2$ $\left(\mathrm{C}_{\text {para }}\right), \quad 129 \quad\left(\mathrm{C}_{\text {meta }}\right), \quad 122.8 \quad\left(\mathrm{C}_{\text {ortho }}\right), \quad 58.7 \quad\left(\mathrm{CH}_{2} \mathrm{CH}_{3}\right), \quad 47.7$ $\left(C^{\prime} \mathrm{H}_{2} \mathrm{CH}_{3}\right), 15.4\left(\mathrm{CH}_{2} \mathrm{CH}_{3}\right), 14.4\left(\mathrm{CH}_{2} \mathrm{C}^{\prime} \mathrm{H}_{3}\right)$.

General procedure for the decomposition of the carbene complexes. Gold complexes: A $5 \mathrm{~mm}$ NMR tube was charged with the neutral $\mathrm{Au}(\mathrm{I})$ carbene (2a or $\mathbf{2 b}, 0.014 \mathrm{mmol}), 0.6 \mathrm{~mL}$ of $\mathrm{CD}_{3} \mathrm{CN}$ and finally stoichiometric amounts of the additive were added if necessary. Copper and silver: Under a $\mathrm{N}_{2}$ atmosphere a 5 mm NMR tube was charged with the silver or copper salt or complex (0.02-0.03 mmol), $0.6 \mathrm{~mL}$ of $\mathrm{CD}_{3} \mathrm{CN}$, and equimolar amounts of the tungsten carbene (1a or $\mathbf{1 b})$ and the additive when needed. The decomposition products of the carbene fragment were characterized by NMR by comparison with authentic samples (6-8). The identity of $\mathbf{1 0}$ was independently corroborated by treatment of $\mathrm{PhCH}=\mathrm{NEt}$ with $\left(\mathrm{OEt}_{3}\right) \mathrm{BF}_{4}$ (see $\left.\mathrm{SI}\right)$.

10: ${ }^{1} \mathrm{H}$ NMR (500 MHz, $\left.\delta, \mathrm{CD}_{3} \mathrm{CN}\right): 8.83$ (s, $1 \mathrm{H}, \mathrm{H}_{\text {iminium }}$ ), 7.85 $\left(\mathrm{m}, 1 \mathrm{H}, \mathrm{H}_{\text {para }}\right), 7.83\left(\mathrm{~m}, 2 \mathrm{H}, \mathrm{H}_{\text {ortho }}\right), 7.76\left(\mathrm{~m}, 2 \mathrm{H}, \mathrm{H}_{\text {meta }}\right), 4.09$ (q, $J$ $\left.=7.36 \mathrm{~Hz}, 2 \mathrm{H}, \mathrm{CH}_{2} \mathrm{CH}_{3}\right), 4.04\left(\mathrm{q}, J=7.36 \mathrm{~Hz}, 2 \mathrm{H}, \mathrm{CH}_{2}{ }_{2} \mathrm{CH}_{3}\right)$, $1.51\left(\mathrm{t}, J=7.36 \mathrm{~Hz}, 6 \mathrm{H}, \mathrm{CH}_{2} \mathrm{CH}_{3}+\mathrm{CH}_{2} \mathrm{CH}_{3}\right) .{ }^{13} \mathrm{C}\left\{{ }^{1} \mathrm{H}\right\} \mathrm{NMR}$ $\left(125.76 \mathrm{MHz}, \delta, \mathrm{CD}_{2} \mathrm{Cl}_{2}\right): 171.2\left(\mathrm{C}_{\text {iminium }}\right), 137.3\left(\mathrm{C}_{\text {para }}\right), 132.6$ $\left(\mathrm{C}_{\text {ortho }}\right), 130.4\left(\mathrm{C}_{\text {meta }}\right), 125.7$ (s, $\left.\mathrm{C}_{\text {ipso }}\right), 57.1\left(\mathrm{CH}_{2} \mathrm{CH}_{3}\right), 49.3$ (s, $\left.C^{\prime} \mathrm{H}_{2} \mathrm{CH}_{3}\right), 12.5$ (s, $\left.\mathrm{CH}_{2} \mathrm{CH}_{3}+\mathrm{CH}_{2} \mathrm{C}^{\prime} \mathrm{H}_{3}\right)$.

Computational methods. The DFT studies were performed with the M06 functional, ${ }^{43,44}$ as implemented in the Gaussian09 program package. ${ }^{45}$ The $6-31+\mathrm{G}(\mathrm{d})$ basis set was used for $\mathrm{C}, \mathrm{O}, \mathrm{S}$, $\mathrm{Cl}, \mathrm{N}$ and $\mathrm{H}^{46,47}$ and LANL2TZ(f) for $\mathrm{Cu}, \mathrm{Ag}, \mathrm{Au}$ and $\mathrm{W}{ }^{48,49}$ (Basis set I). Solvation was introduced in all optimizations, frequency calculations and potential energy refinement through the SMD model, where we applied the experimental solvent, acetonitrile, as the solvent $(\varepsilon=27.9)$. All structure optimizations were carried out in solvent phase with no symmetry restrictions. Free energy corrections were calculated at $298.15 \mathrm{~K}$ and $10^{5} \mathrm{~Pa}$ pressure, including zero point energy corrections (ZPE), and the energies were converted to $1 \mathrm{M}$ standard state in solution (adding/subtracting $1.89 \mathrm{kcal} \mathrm{mol}{ }^{-1}$ for non-unimolecular processes). Vibrational frequency calculations were performed in order to confirm that the stationary points were minima (without imaginary frequencies) or transition states (with one imaginary frequency). Connectivity of the transition state structure was confirmed by relaxing the transition state geometry towards both the reactant and the product. Final potential energies were refined by performing additional single-point energy calculations (also in solution); $\mathrm{Cu}, \mathrm{Ag}, \mathrm{Au}$ and $\mathrm{W}$ were still described with
LANL2TZ(f) basis set, and the remaining atoms were treated with $6-311++G(d, p)$ basis set (Basis set II). All energies presented correspond to free energies in solution, obtained from potential energies (including solvation) with basis set II plus Gibbs energy corrections with basis set I and are given in $\mathrm{kcal} \mathrm{mol}^{-1}$.

\section{ASSOCIATED CONTENT}

Supporting Information. Additional experimental data, selected spectra, and computational details (PDF). Cartesian coordinates of the calculated structures (XYZ). CIF file for complexes 2a and 2b. This material is available free of charge via the Internet at http://pubs.acs.org.

\section{AUTHOR INFORMATION}

\section{Corresponding Author}

Ana C. Albéniz (albeniz@qi.uva.es)

\section{Author Contributions}

The manuscript was written through contributions of all authors. / All authors have given approval to the final version of the manuscript.

\section{Funding Sources}

Spanish MINECO (SGPI, grant CTQ2016-80913-P and PID2019111406GB-I00; fellowship to AT BES-2014- 067770). Junta de Castilla y León (grant VA062G18)

\section{Notes}

The authors declare no competing financial interest.

\section{ACKNOWLEDGMENT}

We thank the financial support of the Spanish MINECO (SGPI, grants CTQ2016-80913-P, PID2019-111406GB-I00 and BES2014-067770 fellowship to A.T.) and the Junta de Castilla y León (grant VA062G18).

\section{REFERENCESS}

(1) (a) Lin, J. C. Y.; Huang, R. T. W.; Lee, C. S.; Bhattacharyya, A.; Hwang, W. S.; Lin, I. J. B. Coinage Metal-N-Heterocyclic Carbene Complexes. Chem. Rev. 2009, 109, 3561-3598. (b) Garrison, J. C.; Youngs, W. J. Ag(I) N-Heterocyclic Carbene Complexes: Synthesis, Structure, and Application. Chem. Rev. 2005, 105, 3978-4008.

(2) (a) Bartolomé, C.; Ramiro, Z.; García-Cuadrado, D.; Pérez-Galán, P.; Raducan, M.; Bour, C.; Echavarren, A. M.; Espinet, P. Nitrogen Acyclic Gold(I) Carbenes: Excellent and Easily Accessible Catalysts in Reactions of 1,6-Enynes. Organometallics 2010, 29, 951-956. (b) Bartolomé, C.; García-Cuadrado, D.; Ramiro, Z.; Espinet, P. Synthesis and Catalytic Activity of Gold Chiral Nitrogen Acyclic Carbenes and Gold Hydrogen Bonded Heterocyclic Carbenes in Cyclopropanation of Vinyl Arenes and in Intramolecular Hydroalkoxylation of Allenes. Inorg. Chem. 2010, 49, 9758-9764. (c) Hashmi, A. S. K.; Hengst, T.; Lothschütz, C.; Rominger F. New and Easily Accessible Nitrogen Acyclic Gold(I) Carbenes: Structure and Application in the Gold-Catalyzed Phenol Synthesis as well as the Hydration of Alkynes. Adv. Synth. Catal. 2010, 352, 1315-1337. (d) Slaughter, L. M. Acyclic Aminocarbenes in Catalysis. ACS Catal. 2012, 2, 1802-1816.

(3) (a) Zeng, X.; Frey, G. D.; Kinjo, R.; Donnadieu, B.; Bertrand, G. Synthesis of a Simplified Version of Stable Bulky and Rigid Cyclic (Alkyl)(amino)carbenes, and Catalytic Activity of the Ensuing Gold(I) Complex in the Three-Component Preparation of 1,2-Dihydroquinoline Derivatives. J. Am. Chem. Soc. 2009, 131, 8690-8696. (b) Melaimi, M Soleilhavoup, M.; Bertrand, G. Stable Cyclic Carbenes and Related Species beyond Diaminocarbenes. Angew. Chem., Int. Ed. 2010, 49, 8810 8849. (c) Soleilhavoup, M.; Bertrand, G. Cyclic (Alkyl)(Amino)Carbenes (CAACs): Stable Carbenes on the Rise. Acc. Chem. Res. 2015, 48, 256266. 
(4) Cheng, Q. -Q.; Doyle, M. P. The Selection of Catalysts for Metal Carbene Transformations. Adv. Organomet. Chem. 2016, 66, 1-31.

(5) (a) Kirmse, W. Copper Carbene Complexes: Advanced Catalysts, New Insights. Angew. Chem. Int. Ed. 2003, 42, 1088-1093. (b) Thompson, J. L.; Davies, H. M. L. Enhancement of Cyclopropanation Chemistry in the Silver-Catalyzed Reactions of Aryldiazoacetates. J. Am. Chem. Soc. 2007, 129, 6090-6091. (c) Briones, J. F.; Davies, H. M. L. Silver TriflateCatalyzed Cyclopropenation of Internal Alkynes with Donor-/AcceptorSubstituted Diazo Compounds. Org. Lett. 2011, 13, 3984-3987. (d) Qian, D.; Zhang, J. Gold-catalyzed cyclopropanation reactions using a carbenoid precursor toolbox. Chem. Soc. Rev. 2015, 44, 677-698

(6) Diaz-Requejo, M. M.; Pérez, P. J. Coinage Metal Catalyzed C-H Bond Functionalization of Hydrocarbons. Chem. Rev. 2008, 108, 33793394; (b) Caballero, A.; Pérez, P. J. Catalyst design in the alkane C-H bond functionalization of alkanes by carbene insertion with $\mathrm{Tp}^{\mathrm{x}} \mathrm{M}$ complexes $\left(\mathrm{Tp}^{\mathrm{x}}=\right.$ hydrotrispyrazolylborate ligand; $\left.\mathrm{M}=\mathrm{Cu}, \mathrm{Ag}\right) . J$. Organomet. Chem. 2015, 793, 108-113. (c) Fructos, M.; Diaz-Requejo, M. M.; Pérez, P. J. Gold and diazo reagents: a fruitful tool for developing molecular complexity. Chem. Commun., 2016, 52, 7326-7335.

(7) (a) Wang, C.; Ye, F.; Wu, C.; Zhang, Y.; Wang, J. Construction of All-Carbon Quaternary Centers through $\mathrm{Cu}-$ Catalyzed Sequential Carbene Migratory Insertion and Nucleophilic Substitution/Michael Addition. J. Org. Chem. 2015, 80, 8748-8757. (b) Che, J.; Xing, D.; Hu, W. MetalCatalyzed Cross-Coupling of Terminal Alkynes with Different Carbene Precursors. Curr. Org. Chem. 2016, 20, 41-60.

(8) Julian, R. R.; May, J. A.; Stoltz, B. M.; Beauchamp, J. L. Gas-Phase Synthesis of Charged Copper and Silver Fischer Carbenes from Diazomalonates: Mechanistic and Conformational Considerations in MetalMediated Wolff Rearrangements. J. Am. Chem. Soc. 2003, 125, 44784486.

(9) (a) Braga, A. A. C.; Caballero, A.; Urbano, J.; Diaz-Requejo, M. M.; Pérez, P. J.; Maseras, F. Mechanism of Side Reactions in Alkane C H Bond Functionalization by Diazo Compounds Catalyzed by $\mathrm{Ag}$ and $\mathrm{Cu}$ Homoscorpionate Complexes-A DFT Study. ChemCatChem. 2011, 3, 1646-1652. (b) Besora, M.; Braga, A. A. C.; Sameera W. M. C.; Urbano, J.; Fructos, M. R.; Pérez, P. J.; Maseras, F. A computational view on the reactions of hydrocarbons with coinage metal complexes. J. Organomet. Chem. 2015, 784, 2-12. (c) Zhang, J.; Shan, C.; Zhang, T.; Song, J.; Liu, T.; Lan, Y. Computational advances aiding mechanistic understanding of silver-catalyzed carbene/nitrene/silylene transfer reactions. Coord. Chem. Rev. 2019, 382, 69-84.

(10) Solorio-Alvarado, C. R.; Wang, Y.; Echavarren, A. M. Cyclopropanation with Gold(I) Carbenes by Retro-Buchner Reaction from Cycloheptatrienes. J. Am. Chem. Soc. 2011, 133, 11952-11955.

(11) (a) Fürstner, A.; Davies, P. W. Catalytic Carbophilic Activation: Catalysis by Platinum and Gold $\pi$ Acids. Angew. Chem. Int. Ed. 2007, 46, 3410-3449. (b) Jiménez-Núñez, E.; Echavarren, A. M. Gold-Catalyzed Cycloisomerizations of Enynes: A Mechanistic Perspective. Chem. Rev. 2008, 108, 3326-3350. (c) Dorel, R.; Echavarren, A. M. Gold(I)Catalyzed Activation of Alkynes for the Construction of Molecular Complexity. Chem. Rev. 2015, 115, 9028-9072.

(12) (a) Seidel, G.; Mynott, R.; Fürstner, A. Elementary Steps of Gold Catalysis: NMR Spectroscopy Reveals the Highly Cationic Character of a "Gold Carbenoid". Angew. Chem. Int. Ed. 2009, 121, 2510-2513. (b) Wang, Y.; Muratore, M. E.; Echavarren, A. M. Gold Carbene or Carbenoid: Is There a Difference? Chem. Eur. J. 2015, 21, 7332-7339. (c) Harris, R. J.; Widenhoefer, R. A. Gold carbenes, gold-stabilized carbocations, and cationic intermediates relevant to gold-catalysed enyne cycloaddition. Chem. Soc. Rev., 2016, 45, 4533-4551.

(13) (a) Ung, G. Soleilhavoup, M.; Bertrand, G. Gold(III)-versus Gold(I)-Induced Cyclization: Synthesis of Six- Membered Mesoionic Carbene and Acyclic (Aryl)(Heteroaryl) Carbene Complexes. Angew. Chem. Int. Ed. 2013, 52, 758 -761. (b) Seidel, G.; Fürstner, A. Structure of a Reactive Gold Carbenoid. Angew. Chem. Int. Ed. 2014, 53, 48074811. (c) Harris, R. J.; Widenhoefer, R. A. Synthesis, Structure, and Reactivity of a Gold Carbenoid Complex That Lacks Heteroatom Stabilization. Angew. Chem. Int. Ed. 2014, 53, 9369 -9371. (d) Hussong, M. W.; Rominger, F.; Krämer, P.; Straub, B. F. Isolation of a Non-HeteroatomStabilized Gold-Carbene Complex. Angew. Chem. Int. Ed. 2014, 53 , 9372-9375. (e) Joost, M.; Estévez, L.; Mallet-Ladeira, S.; Miqueu, K.; Amgoune, A.; Bourissou, D. Enhanced p-Backdonation from Gold(I) Isolation of Original Carbonyl and Carbene Complexes. Angew. Chem. Int. Ed. 2014, 53, 14512-14516. (f) García-Morales, C.; Pei, X. -L.; Sarria Toro, J. M.; Echavarren, A. M. Direct Observation of Aryl Gold(I) Car- benes that Undergo Cyclopropanation, $\mathrm{C}-\mathrm{H}$ Insertion, and Dimerization Reactions. Angew. Chem. Int. Ed. 2019, 58, 3957-3961.

(14) (a) Straub, B. F.; Hofmann, P. Copper(I) Carbenes: The Synthesis of Active Intermediates in Copper-Catalyzed Cyclopropanation. Angew. Chem., Int. Ed. 2001, 40, 1288-1290. (b) Dai, X.; Warren, T. H. Discrete Bridging and Terminal Copper Carbenes in Copper-Catalyzed Cyclopropanation. J. Am. Chem. Soc. 2004, 126, 10085-10094. (c) Mankad, N. P.; Peters, J. C. Diazoalkanes react with a bis(phosphino)borate copper(I) source to generate $\left[\mathrm{Ph}_{2} \mathrm{BP}^{t} \mathrm{Bu}_{2}\right] \mathrm{Cu}\left(\eta^{1}-\mathrm{N}_{2} \mathrm{CR}_{2}\right),\left[\mathrm{Ph}_{2} \mathrm{BP}^{\mathrm{t}} \mathrm{Bu}_{2}\right] \mathrm{Cu}\left(\mathrm{CPh}_{2}\right)$, and $\left[\mathrm{Ph}_{2} \mathrm{BP}^{t} \mathrm{Bu}_{2}\right] \mathrm{Cu}-\mathrm{N}\left(\mathrm{CPh}_{2}\right)\left(\mathrm{NCPh}_{2}\right)$. Chem. Commun. 2008, 1061-1063. (d) Hofmann, P.; Shishkov, I. V.; Rominger, F. Synthesis, Molecular Structures, and Reactivity of Mono- and Binuclear Neutral Copper(I) Carbenes. Inorg. Chem. 2008, 47, 11755-11762. (e) Bidal, Y. D.; Lesieur, M.; Melaimi, M.; Cordes, D. B.; Slawin, A. M. Z.; Bertrand, G.; Cazin, C. S. J. A simple access to transition metal cyclopropenylidene complexes. Chem. Commun. 2015, 51, 4778-4781. (f) Pereira, A.; Champouret, Y.; Martín, C.; Álvarez, E.; Etienne, M.; Belderraín, T. R.; Pérez, P. J. Copper-Carbene Intermediates in the Copper-Catalyzed Functionalization of O-H Bonds. Chem. Eur. J. 2015, 21, 9769-9775. (g) Hoffmeister, W. T.; Rominger, F.; Straub, B. F. Copper and Silver Carbene Complexes without Heteroatom- Stabilization: Structure, Spectroscopy, and Relativistic Effects. Angew. Chem. Int. Ed. 2015, 54, 10331-10335.

(15) Batiste, L. Chen, P. Coinage-Metal Mediated Ring Opening of cis1,2- Dimethoxycyclopropane: Trends from the Gold, Copper, and Silver Fischer Carbene Bond Strength. J. Am. Chem. Soc. 2014, 136, 9296-9307.

(16) The representation of the carbene fragment used here for the group 11 metal complexes tries to reflect, whenever possible, the structural data found here or in analogous complexes in the literature: $\mathrm{M}-\mathrm{C}$ (carbene) single bonds and $\mathrm{C}=\mathrm{X}$ double bonds $(\mathrm{X}=$ heteroatom, formal charges are omitted). However, the traditional representation of the $\mathrm{M}=\mathrm{C}$ double bond is kept in the tungsten derivatives and in those cases where, the $\mathrm{M}-$ $\mathrm{C}$ (carbene) single bond representation could be mistaken with an alkyl derivative (M-CRR', for example).

(17) (a) Pérez-Mateo, A.; Manrique, R.; Espinet, P.; Albéniz, A. C. Observation of the Direct Products of Migratory Insertion in Aryl Palladium Carbene Complexes and Their Subsequent Hydrolysis. Angew. Chem. Int. Ed. 2002, 41, 2363-2366. (b) Pérez-Mateo, A.; Manrique, R.; Espinet, P.; Albéniz, A. C. Aryl Palladium Carbene Complexes and Carbene-Aryl Coupling Reactions. Chem. Eur. J. 2005, 11, 1565-1573. (c) Meana, I.; Albéniz, A. C.; Espinet, P. Acyl-Carbene and Methyl-Carbene Coupling via Migratory Insertion in Palladium Complexes. Organometallics 2012, 31, 5494-5499. (d) Meana, I.; Toledo, A.; Albéniz. A. C.; Espinet, P. Detection and Reactivity of a Palladium Alkoxycarbene. Chem. Eur. J. 2012, 18, 7658-7661.

(18) (a) Gómez-Gallego, M.; Mancheño, M. J.; Sierra, M. A. Catalytic Transmetalation from Group 6 Fischer Carbene Complexes: An Emerging Powerful Tool in Organic Synthesis. Acc. Chem. Res. 2005, 38, 44-53. (b) Fernández, I.; Mancheño, M. J.; Vicente, R.; López, L. A.; Sierra, M. A. Transmetalation Reactions from Fischer Carbene Complexes to Late Transition Metals: A DFT Study. Chem. Eur. J. 2008, 13, 11222-11230.

(19) Borge, J.; Álvarez-Rúa, C.; García-Granda, S.; Tomás, M.; Löber, O.; López, L. A.; Barluenga, J. Chromium-Copper Exchange of Fischer Carbene Complexes: X-Ray Crystal Structure of a $\left[\mathrm{Cu}\left\{=\mathrm{CR}^{1}\left(\mathrm{OR}^{2}\right)\right\}(\mathrm{MeCN})\left(\mathrm{Et}_{2} \mathrm{O}\right)\right]$ Complex. Angew. Chem. Int. Ed. 2001, 40, 3392-3394

(20) (a) Fischer, E. O.; Aumann, R. New Gold Carbene Complexes via Carbene Transfer Reactions. Chem. Ber. 1981, 114, 1853-1857. (b) Fañanás-Mastral, M.; Aznar, F. Carbene Transfer Reactions from Chromium(0) to Gold(I): Synthesis and Reactivity of New Fischer-Type Gold(I) Alkenyl Carbene Complexes. Organometallics 2009, 28, 666668. (c) Strasser, C. E.; Cronje, S.; Raubenheimer, H. G. Fischer-type tungsten acyl (carbeniate), carbene and carbyne complexes bearing C5attached thiazolyl substituents: interaction with gold(I) fragments. New J. Chem. 2010, 34, 458-469. (d) Seidel, G.; Gabor, B.; Goddard, R.; Heggen, B.; Thiel, W.; Fürstner, A. Gold Carbenoids: Lessons Learnt from a Transmetalation Approach. Angew. Chem., Int. Ed. 2014, 53, 879-882. (e) Brooner, R. E.; Widenhoefer, R. A. Experimental evaluation of the electron donor ability of a gold phosphine fragment in a gold carbene complex. Chem. Comm. 2014, 2420-2423. (f) Bezuidenhout, D. I.; van der Westhuizen, B.; Rosenthal, A. J.; Wörle, M.; Liles, D. C.; Fernández, I. Fischer-type gold(I) carbene complexes stabilized by aurophilic interactions. Dalton Trans. 2014, 43, 398-401.

(21) The X-ray molecular structure of $\left[\mathrm{AuCl}\left\{\mathrm{CPh}\left(\mathrm{NMe}_{2}\right)\right\}\right]$, very close to complex 2a, has already been reported: Schubert, U.; Ackermann, K.; 
Aumann, R. Chloro[dimethylamino(phenyl)carbene]gold(I), $\mathrm{ClAuC}\left(\mathrm{C}_{6} \mathrm{H}_{5}\right) \mathrm{N}\left(\mathrm{CH}_{3}\right)_{2}$. Cryst. Struct. Commun. 1982, 11, 591-594.

(22) The Au- $\mathrm{C}_{\text {carbene }}$ bond lengths for $[\mathrm{ClAu}$ (carbene) $]$ complexes are slightly shorter than those for $[\mathrm{LAu}(\text { carbene })]^{+}\left(\mathrm{L}=\mathrm{PR}_{3}, \mathrm{NHC}\right)$ as it is expected according to the higher trans influence of the latter ligands. See examples in reference 20.

(23) Fernández, I.; Cossío, F. P.; Arrieta, A.; Lecea, B.; Mancheño, M. J.; Sierra, M. A. Structure and Conformations of Heteroatom-Substituted Free Carbenes and Their Group 6 Transition Metal Analogues. Organometallics, 2004, 23, 1065-1071.

(24) (a) Aumann, R.; Hinterding, P.; Kriiger, C.; Goddard, R. Organische Synthesen mit obergangsmetall-Komplexen LXV. Aldehyde durch Hydrolyse der $\mathrm{M}=\mathrm{C}$-Bindung von Alkoxycarben-Chromkomplexen mit Wasser/ Urotropin. Ein zweikerniger verbriickter ( p-Amino)vinylcarbenChromkomplex durch Fragmentierung von Urotropin. J. Organomet. Chem. 1993, 459, 145-149. (b) Bernasconi, C. F. Developing the physical organic chemistry of Fischer carbene complexes. Chem. Soc. Rev. 1997, 26, 299-307; (c) Pérez, G. S.; Bernasconi, C. F. Physical Organic Chemistry of Transition Metal Carbene Complexes. 21. Kinetics and Mechanism of Hydrolysis of $(\mathrm{CO}) 5 \mathrm{M}=\mathrm{C}(\mathrm{SR}) \mathrm{Ar} \quad\left(\mathrm{M}=\mathrm{Cr}\right.$ and $\mathrm{W} ; \mathrm{R}=\mathrm{CH}_{3}$ and $\mathrm{CH}_{3} \mathrm{CH}_{2} \mathrm{CH}_{2} ; \mathrm{Ar}=\mathrm{C}_{6} \mathrm{H}_{5}$ and 3- $\left.\mathrm{ClC}_{6} \mathrm{H}_{4}\right)$ in Aqueous Acetonitrile. Important Differences Relative to Complexes with Alkoxy Leaving Groups. J. Am. Chem. Soc. Rev. 2000, 122, 12441-12446; (d) Bhattacharya, S.; Bernasconi, C. F. Physical Organic Chemistry of Transition Metal Carbene Complexes. 29. Kinetics of Reactions of [Ethoxy(phenyl)carbene]pentacarbonylchromium $(0)$ and [Ethoxy $($ phenyl $)\left(\mathrm{Cr}(\mathrm{CO})_{3}\right)$ carbene]pentacarbonylchromium( $(0)$ with Water, $\mathrm{OH}-$, and Amines. Mechanistic Changes Induced by the $\mathrm{Cr}(\mathrm{CO})_{3}$ Group. Organometallics 2004, 23, 1722-1729; (e) Shin, G.-C.; Hwang, J.; Yang, K.; Koo, I. S.; Lee, I. Kinetics and Mechanism of Alkaline Hydrolysis of [(Methoxy)(psubstituted styryl)carbene] Pentacarbonyl Chromium(0) Complexes in Aqueous Acetonitrile. Bull. Korean. Chem. Soc. 2005, 26, 1981-1985.

(25) For some examples of Au-acyl complexes: (a) Raubenheimer, H. G.; Esterhuysen, M. W.; Esterhuysen, C. Gold acyls and imidoyls prepared from anionic Fischer-type carbene complexes. Inorg. Chim. Acta 2005, 358, 4217-4228. (b) Bucher, J.; Stößer, T.; Rudolph, M.; Rominger, F.; Hashmi, A. S. K. CO Extrusion in Homogeneous Gold Catalysis: Reactivity of Gold Acyl Species Generated through Water Addition to Gold Vinylidenes. Angew. Chem. Int. Ed. 2015, 54, $1666-1670$.

(26) The identity of the $[\mathrm{Au}]$ species in the formation of $\mathbf{B}$ is more difficult to rationalize. A bimolecular reductive decomposition pathway leading to $\mathrm{Au}(0)$ may occur. As mentioned before, the change in color of the solution to purple is observed, suggesting the formation of Au nanoparticles.

(27) López, L. A.; Barrio, P.; Borge, J. Cationic Copper(I) Carbene Complexes: Synthesis and Structures of a Tricoordinate Copper(I) Carbene Water Complex and a Dicoordinate Carbene Complex. Organometallics 2012, 31, 7844-7848.

(28) Del Amo, J. C.; Mancheño, M. J.; Gómez-Gallego, M.; Sierra, M. A. Catalytic Transmetalation of Alkoxychromium(0) Carbenes to Late Transition Metals: Self-Dimerization and Cyclopropanation Reactions. Organometallics 2004, 23, 5021-5029.

(29) Sierra, M. A.; del Amo, J. C.; Mancheño, M. J.; Gómez-Gallego, M. J. Catalytic Transmetalation of Alkoxychromium(0) Carbenes to Late Transition Metals: Self-Dimerization and Cyclopropanation Reactions. $J$. Am. Chem. Soc. 2001, 123, 851-861.

(30) Klet, R. C.; Labinger, J. A.; Bercaw, J. E. Diverse C C BondForming Reactions of Bis(carbene)platinum(II) Complexes. Organometallics, 2012, 31, 6652-6657.

(31) The increase in the coordination number of silver by coordination of an extra NCMe ligand in 1a-Ag does not lead to a more stable intermediate that could facilitate the carbene transfer and the energy of 1a-Ag$\mathrm{NCMe}$ is $3 \mathrm{kcal} \mathrm{mol}^{-1}$ higher than $\mathbf{1 a - A g}$.

(32) We corroborated that the hydrolysis of the iminium led to benzaldehyde by the addition of $\mathrm{H}_{2} \mathrm{O}$ to the reaction mixture after $6 \mathrm{~h}$ in the conditions of entry 2, Table 4 , which contained 10, and observing the immediately conversion to $\mathbf{8}$. We also corroborated that the aldehyde proton exchange with deuterium is slow in our conditions by addition of some drops of $\mathrm{D}_{2} \mathrm{O}$ to a solution of benzaldehyde in $\mathrm{CD}_{3} \mathrm{CN}$.

(33) Fischer, E. O.; Schmid, K. R.; Kalbfus, W.; Kreiter, C. G. On the Reaction of Hydrogen Chloride and Hydrogen Bromide with (Aminocarbene)pentacarbonyl Complexes of Chromium and Tungsten. Chem. Ber. 1973, 106, 3893-3909.
(34) Wulfsberg, G. Principles of Descriptive Inorganic Chemistry, 1991, Ed. University Science Books.

(35) Tskhovrebov, A. G.; Goddard, R.; Fürstner, A. Two Amphoteric Silver Carbene Clusters. Angew. Chem. Int. Ed. 2018, 57, 8089 -8094.

(36) Fischer, E. O.; Kreibl, F. R. Synthetic Methods of Organometallic and Inorganic Chemistry, Thieme, Stuttgart, 1997, 129-131.

(37) Fischer, E. O.; Schubert, U.; Fischer, H. Carbene complexes obtained by nucleophilic substitution. Pentacarbonyl [(dimethylamino)phenylmethylene]tungsten(0). Inorg. Synth. 1979, 19, 169-171.

(38) Usón, R.; Laguna, M. Tetrahydrothiophene)gold(I) or gold(III) complexes. Chloro(tetrahydrothiophene)gold(I). Inorg. Synth. 1989, 26, 85-91.

(39) Bravo, O.; Iwamoto, R. T. The chloro complexes of gold(I) in acetonitrile and comparison with those of copper(I) and silver(I). Inorg. Chim. Acta 1969, 3:4, 663-666.

(40) Llu, J.; Xiao, R.; Wong, Y.-L.; Zhou, X.-P.; Zeller, M.; Hunter, A. D.; Fang, Q.; Liao, L.; Xu, Z. Made in Water: A Stable Microporous $\mathrm{Cu}(\mathrm{I})$-carboxylate Framework (CityU-7) for $\mathrm{CO}_{2}$, Water, and Iodine Uptake. Inorg. Chem. 2018, 57, 9, 4807-4811.

(41) Solari, E.; De Angelis, S.; Latronico, M.; Floriani, C.; ChiesiVilla, A.; Rizzoli, C. Journal of Cluster Science, 1996, Vol. 7. No 4, 553566.

(42) Norén, B.; Oskarsson Å. On the Cubane versus the Stella Quadrangula Structure. The Crystal Structure of Tetrakis[iodo (tetrahydrothiophene)silver(I)]. Acta Chem. Scand, A 1985, 39, 701-709.

(43) Zhao, Y.; Truhlar, D. G. J. A new local density functional for main-group thermochemistry, transition metal bonding, thermochemical kinetics, and noncovalent interactions. Chem. Phys. 2006, 125, 194101-194118.

(44) Zhao, Y.; Truhlar, D. G. The M06 suite of density functionals for main group thermochemistry, thermochemical kinetics, noncovalent interactions, excited states, and transition elements: two new functionals and systematic testing of four M06-class functionals and 12 other functionals. Theor. Chem. Acc. 2006, 120, 215-241.

(45) Gaussian 09, Revision D.01, Frisch, M. J.; Trucks, G. W.; Schlegel, H. B.; Scuseria, G. E.; Robb, M. A.; Cheeseman, J. R.; Scalmani, G.; Barone, V.; Mennucci, B.; Petersson, G. A.; Nakatsuji, H.; Caricato, M.; Li, X.; Hratchian, H. P.; Izmaylov, A. F.; Bloino, J.; Zheng, G.; Sonnenberg, J. L.; Hada, M.; Ehara, M.; Toyota, K.; Fukuda, R.; Hasegawa, J.; Ishida, M.; Nakajima, T.; Honda, Y.; Kitao, O.; Nakai, H.; Vreven, T.; Montgomery, J. A., Jr.; Peralta, J. E.; Ogliaro, F.; Bearpark, M.; Heyd, J. J.; Brothers, E.; Kudin, K. N.; Staroverov, V. N.; Kobayashi, R.; Normand, J.; Raghavachari, K.; Rendell, A.; Burant, J. C.; Iyengar, S. S.; Tomasi, J.; Cossi, M.; Rega, N.; Millam, J. M.; Klene, M.; Knox, J. E.; Cross, J. B.; Bakken, V.; Adamo, C.; Jaramillo, J.; Gomperts, R.; Stratmann, R. E.; Yazyev, O.; Austin, A. J.; Cammi, R.; Pomelli, C.; Ochterski, J. W.; Martin, R. L.; Morokuma, K.; Zakrzewski, V. G.; Voth, G. A.; Salvador, P.; Dannenberg, J. J.; Dapprich, S.; Daniels, A. D.; Farkas, Ö.; Foresman, J. B.; Ortiz, J. V.; Cioslowski, J.; Fox, D. J. Gaussian, Inc., Wallingford CT, 2009.

(46) Francl, M. M.; Petro, W. J.; Hehre, W. J.; Binkley, J. S.; Gordon, M. S.; DeFrees, D. J.; Pople, J. A. Self-consistent molecular orbital methods. XXIII. A polarization-type basis set for second-row elements. $J$. Chem. Phys. 1982, 77, 3654-3665.

(47) Clark, T.; Chandrasekhar, J.; Schleyer, P. V. R. J. Efficient diffuse function-augmented basis sets for anion calculations. III. Thee $3-21+G$ basis set for first-row elements, Li-F. Comput. Chem. 1983, 4, 294-301.

(48) Ehlers, A. W.; Böhme, M.; Dapprich, S.; Gobbi, A.; Höllwarth, A.; Jonas, V.; Köhler, K. F.; Stegmann, R.; Veldkamp, A.; Frenking, G. Chem. Phys. Lett. 1993, 208, 111-114.

(49) Roy, L. E.; Hay, P. J.; Martin, R. L. J. Revised Basis sets for the LANL Effective Core Potentials Chem. Theory Comput. 2008, 4, $1029-1031$. 